
<smiles>CCCCCCCCCCCCCC=C(C)C</smiles> 




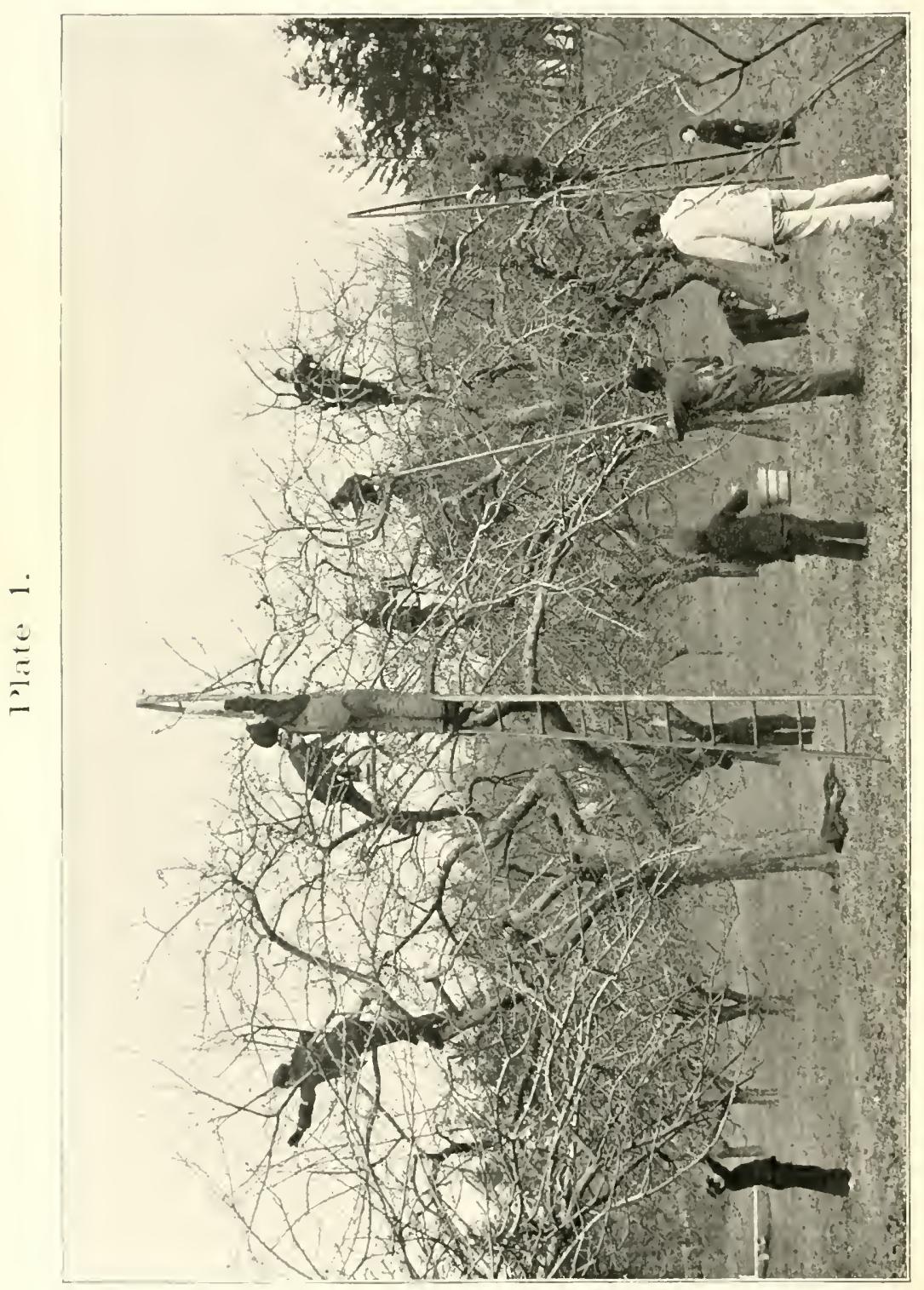

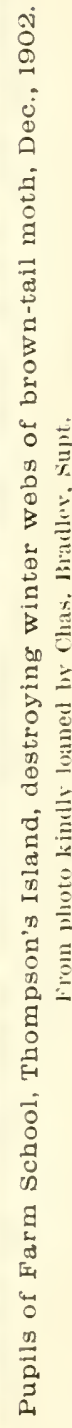




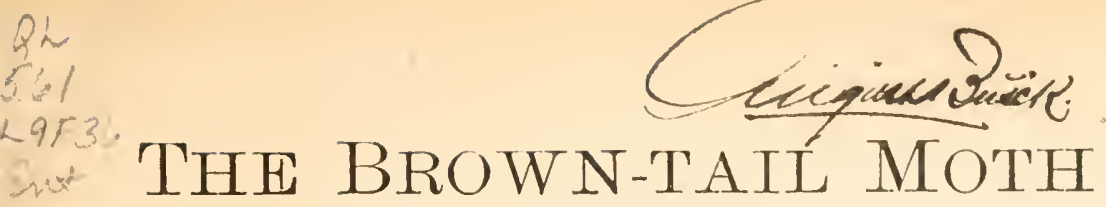

EUPROCTIS CIIRYSORRHEA (L.).

\title{
A REPORT ON THE
}

\section{LiFE HISTORY AND Habits OF THE TMPORTED BROWN-TAIL MOTH,}

\author{
TOGETHER WITH A \\ DESCRHPTON OF THE REMEIMES JEST SUITED \\ FOR DESTROYING IT.
}

BY

Charles H. Fernald, A.M., Ph.D., ani

Arcine H. Kirkland, M.S.
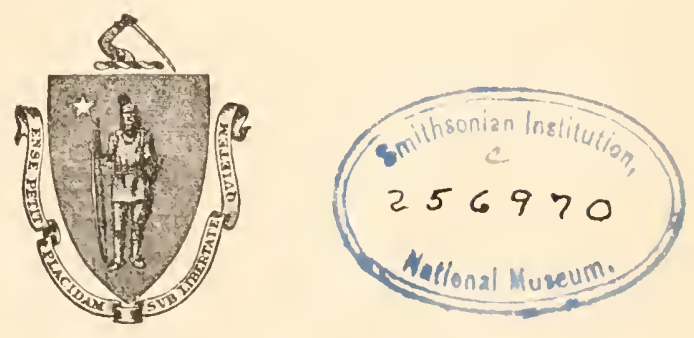

BOSTON :

WRIGHT \& POTTER PRINTING CO., STATE PRINTERS,

18 Post Ofrice Square.

1903. 
$\because 7 x)=$

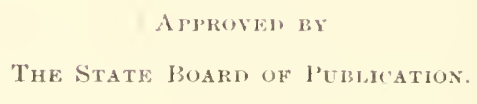




\section{Commontorealth of a}

OfFice of the Massachusetts State Buard of Agriculture, Boston, March 2, 190:3.

I have the honor to submit herewith the special report on the life history and labits of the imported brown-tail moth (Euproctis chrysorrhoea), prepared under authority of chapter 42 of the Resolves of 1902 . The work of preparing this report was delegated to Prof. C. H. Fernald and Mr. A. H. Kirkland, whose careful studies of the insect have made them entirely familiar with its habits. It has been the aim of the authors to present fucts of practical value to the property owner, rather than technical details; and it is hoped that the report will help our citizens to a better understanding of the habits of the moth and methods for destroying it.

Respectfully submitted,

JAMES W. STOCKWELL. 



\section{THE BROWN-TAIL, MOTH.}

Nearly two centuries ago the famous French entomologist, Reaumur, wrote with delightful aecuracy on the habits and life history of a catcrpillar, which, from its wide distribution and frequent oceurrence, he called "la commune," - the common caterpillar. He deseribed the strange habit of the caterpillar's in wintering half grown in a common web; their ravages in the spring in orchard and field; and their feeding, growth and transformation into white moths with bodies tipped with a golden band, - a marking that at once explains the more fumiliar name, "the brown-tail moth." This insect is indeed common in Europe, and occurs wherever the pear and apple flourish. In England, France and Germany its record is one of frequent damage to fruit and shade trees, to shrubs and flowering plants; while at intervals it has appeared in prodigious numbers, causing outbreaks that became matters of historical importance, and resulting in severe loss and grave alarm on the part of aftlicted property owners.

Such, in brief, is the brown-tail moth: in summer, a snow-white, brown-tailed moth, laying its egges on the leaves of pear and many other trees; in August, myriads. of tiny caterpillars, feeding on the tender foliage at the tips of twigs ; in winter, hibernating safely in a tight silken web; in spring, sallying forth to eomplete their growth on bud, blossom and leaf; in . June, ending the life cycle in cocoons from which the moths emerge by the middle of July. A paragraph will give a synopsis of its known life history; a rolume would not record its damage in the old world, or the full importance of its unfortmate introduction into the new; in fact, we do not know as yet just what rôle this insect is to play in our horticultural operations, 
how many erops it will attack with severity, or how far it will spread.

In the present report we lave attempted to give a plain statement of what is known of the habits of this most injurious and annoying inseet, with remedies best suited for its destruction. While the authors have collaborated throughout the entire work, the parts pertaining to the European history and the biology of the moth have been largely prepared by Professor Fernald, while the history of the moth in Massachusetts and the chapter on remedies have received special attention from Mr. Kirkland. I large part of the experinents on the moth, and nearly all the field observations on its habits, were made by us monder the direetion of the gypes moth committer in 18:17-9!9: and to this committee, whose fathful halors have been of such signal value to the state, we are specially indebted for many furors in ronnection with this report.

\section{Discoveliy of the Motil.}

In the spring of 1897 several residents of Somerville and Cambriche, Matsis, found a strange caterpillar feeding on the unfolding leaves of pear trees. Apparently the insects came from small, tomgh webs at the tips of the twigs, particularly at the tops of the trees. They worked downward, consuming the foliage as they mored, and daily grew in size. By the time the foliage was two-thirds developed, the naked tree tops tipped with the graty abandoned webs were conspieuous objects in the infested district. The outbreak at that time was not widespread, but several thrifty property owners noticed with alarm the inroads the insects were daily making on the trees. When the damage by these insects was first observed, the campaign against the rypy moth was being prosecuted rigorously under the amspices of the State Board of I grienlture: and the oflies of the gypsy moth committee at Malden naturally was regarded as an information bureau on all matters pertaining to insect depredations. Danage by the gypo moth was well known, and dreaded correspondingly. Property owners finding new or strange insects on trees or crops frequently mistook them 
for gypsy moths, and requested information or help from the committee, in order to suppress the insects.

In this way Mr. Joseph B. Pike, living at 51 Preston Street, Somerville, Mass., noticing the work of the strange caterpillar, on May 8, 1897, sent word to the office of the gypsy moth. committee that an insect which he supposed to be the gypsy moth was destroying his pear trees. This complaint was promptly investigated by an agent of the committee, Mr. Fleteher Osgood, who reported that an insect, presumably the tent caterpillar, was at work on the pear trees; and Mr. Pike was advised to spray the trees with some arsenical poison.

A second complaint of damage was received May 14 from the well-known mycologist of Harvard University, I)r. Roland Thaxter, and similar injury to pear trees was observed. The unusual feature of a tent-making caterpillar at work in the spring on pear trees aroused the interest of Mr. Kirkland, at the time assistant entomologist to the gypsy moth committee. Securing specimens, and not being ablo to identify the insects off hand, he commenced to rear them, in order that the species might be identified from the mature moths. Following Dr. Thaxter's eomplaint concerning the insect, other reports of damage came in rapidly to the grpsy moth office, and in the course of a few days it was evident that an insect outbreak of extraordinary nature was taking place in Somerrille and Cambridge. Specimens of the caterpillar were given to Prof. C. H. Fernald, entomologist to the committee, by Mr. Kirkland, who, being struck with the similarity of the hatbits of the caterpillars to those of the brown-tail moth as described in European literature, suggested to Professor Fernald that this new insect might possibly be that notorious pest. On his return to Amherst Professor Fernald compared the insects with figures and deseriptions of the brown-tail moth in the European works, and at once was able to identify them as the brown-tail moth.

This identification promptly ruised the interesting question of how these insects had beeome colonized in the locality where they were found. To obtain light on this point, careful examination of the infested district was made, and a 
number of owner's of infested estates were interviewed. In this way a latge amount of valuable information was obtained, but, an might be expected, a considerable part of it evidently pertained to depredations of insects other than the browntail moth. Eliminating these statements, there was still abundant evidence that the moth had been established in somerville for several year's previous to 1897 , gradually beconing acclimated, and slowly spreading outward into noninfested territory. Many of these statements from owners of infested property were of especial interest, and it is well to record several of the more important at this point.

Mr. IV. I. ('hase, living at 85 Vine Street, Somerville, Mass., stated that he moved to his present place in 1892. In the spring of that rear the "aterpillar's of the brown-tail moth defoliated a few pear trees, and then, driven by want of fool, deseended to the ground and attacked rlubarb and other plants, greatly injuring his garden crops. Since that date the caterpillar's were more or less abundant each year, and in May, 1s!) 7 , had stripped nearly all the fruit and shade trees on his place. Mrs. Chase stated that in the summer of 189 is the house and buildings adjacent "fatrly swarmed with white moths."

Mr. .I. A. Merrificld, 486 somerville Avenue, Somerville, Masis, hatd noticed the webs of the brown-tail moth on his pear trees for at least three years preceding 1897 , and up to that youl had cut ofl' and destroyed the webs each winter, thus applying of his own initiative the best remedy for preventing dandage by the moth. $A$ s a result of this treatment, his trees were preserved from damage, while those of his neighbors were more or less defoliated. Owing to other duties in 1897 , this work of web destruction was neglected until Patriotis Daty, April 19, when they were destroyed as usial. This date proved too late, as the eaterpillars had cmereed and were cratsling over the trees in great numbers, and as a result many of the trees were dofoliated. Mr. Merrificld stated that he examined several webs April 1, and fornd that they contained masses of caterpillar's, hence thought it sate to delay treatment until the holiday mentioned. Particular interest attaches to Mr. Merrifield's state- 
ment, as he is a conservative man, and possesses a good general knowledge of our common insect pests.

Mr. H. Foster, 23 Park Strcet, Somerville, Misss, removed and burned the tents on his trees each spring from 1895 to 1897. This was done before the eaterpillar's left the wels;, and as a result his trees retained their foliage, while those of his neighbors were almost entirely defoliated.

Mr. John Walker, living at 2 Amold Court, Somerville, Mass., stated that for more than three years previous to 1897 he had noticed damage by these caterpillar's, the number of the insects increasing each year.

These statements indicate that the moth had been sufficiently numerous to cause noticenble injury since $1892-94$. It is entirely probable that it oceurred in small, numbers for several years before it was noticed by property owner's, so that it is safe to sot the date of its introduction tentatively at about 1890 . The question has been raised why the moth was not diseovered at an early date by the employees of the gypsy moth committee. This is explained by the fact that in the part of somerville where the moth was found the gypsy moth foree had not worked for several years. Further than that, these men were obliged by law to contine their work to the gypsy moth, henee did not pay special attention to other inserts unless they became injuriously abundant.

\section{Introdection of the Motir.}

It seemed entirely probable that the place of the original introduction of the moth would be found in the worst-infested locality, as the insects would naturally increase in numbers and spread outward from year to year. An examination of the territory showed that the area of greatest damage was near the Somerville depot on the Fitchburg Railroad. Here by the middle of . Iune the devastation had become truly formidable. Pear and apple trees were entirely defoliated, shade trees suffered severely, while even shrubs and horbage were not exempt from the attacks of the ravenous insects. Travelling outward in any direction from this point as a centre the damage by the moth grarlually grew less, until at a distance of between one and two miles the infestations 
of the moth were merely sporadic and localized. Within the badly infested area there were two establishments which, from an entomologieal stand-point, were of a highly suspi(cious chararter, viz, an old ahandoned nursery and a large greenhouse and thorist's plant.

Realizing how easily the insects in their closely spun webs might have been imported on nursery stock, the old nursery was earefully examined and the history of importations there made was investigated. It appeared that the nursery had not been in active operation since about 1895 , and many of the trees left standing in the old nursery rows had attained to a large size. Among the latter there were several large specimens of Pyrus, a genus particularly favored by the caterpillar. Had the insect been introduced here, the nursery, with its surrounding yards, containing numerous fruit trees of eonsiderable age, would have offered ideal conditions for the multiplication of the moth, and here we would have found ample evidence of long-continued infestation. On the contrary, however, careful examination of the nursery and the surrounding estates showed less than a dozen trees infested by the caterpillars.

Owing to the ampopularity of the moth, questions tending to connect any one with its importation were necessarily made in a guarded manner. The second suspicions place, the tlorist's establishment, perhaps one-fourth of a mile from the nursery, was visited, and the proprietors were questioned indirectly with reference to their importations of foreign peremnials or shrubs. lt was found that previons to about 1890 these parties had made a feature of importing roses from Holland and France, growing them for a year or two in large plots in the rear of the greenhouses, and then marketing them. Immediately in the rear of these plots were two blocks of large, full-grown pear trees, and these trees were eompletely defoliated by the aterpillars, and had a history of repeated defoliations extending backward for three or four years. Now, it is well known that the browntail moth occurs both in Holland and France; that in these countries it is not an uneommon pest of roses, - in fuct, it is frepuently mentioned in literature as being one of the 


\section{Plate 2.}

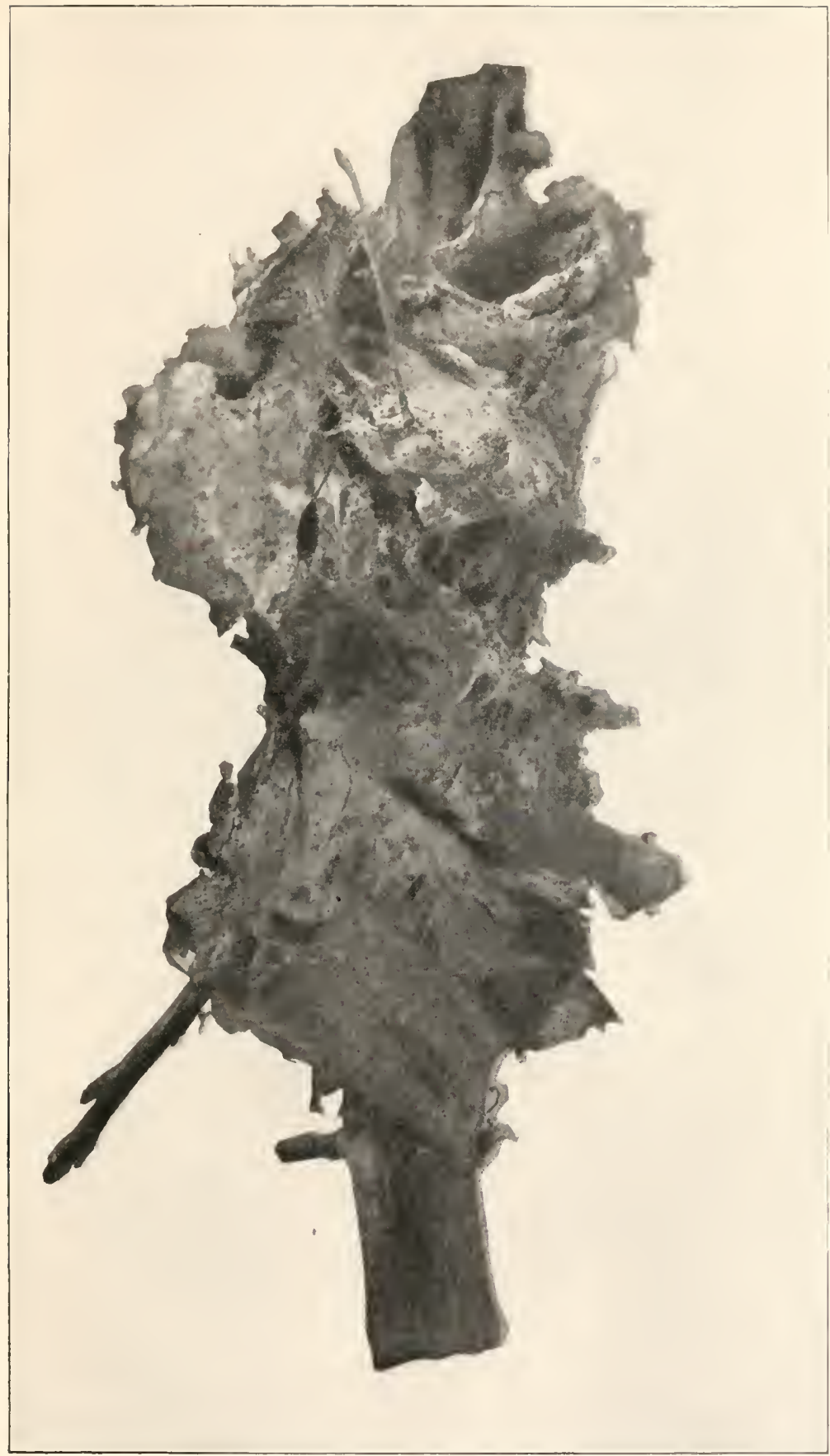

Large web of brown-tall moth on apple. This web was made by the consolidation of several colonies and contained 2218 small caterpillars. 

important pests of roses. We know that it spins its winter webs tireely on the rose, and that rose bushes are always imported in the fall, winter or spring, while both the bushes and the insects are in a dormant comlition. The fact that this greenhouse was in the centre of the worst moth-infested distriet, and in consideration of the facts previously enumerated, makes the circumstantial evidence strong that the brown-tail moth was brought to this locality aceidentally on imported roses, escaped, and spread naturally throughout the district. This case is but another excellent illustration of how the agencies of commerce and the busincss intercourse between nations are fast bringing about a worldwide distribution of our prineipal insect pests.

"It is indeed a strange fatality that another European insect, closely related to the grpsy moth by habit and structure, should become accidentally imported to the same locality to which thirty years before a misguided scientist brought the gypsy moth. It would seem that the world is large enough to give earh of these pests a scparate "sphere of influence.' That they were both transported across the Atlantic to the same locality by totally dissimilar agencies must stand as one of the remarkable entomological events of the century just elosed." * Now that we know the habits of the caterpillar's in spinning their webs on so many diflerent slurubs and trees valued for their fruit or for ornamental purposes, it seens all the more remarkable that the insect was not imported years ago. Our long inmmuty from the pest in greatly to the eredit of Emopean nurserymen, and gives evidence of the "are with which nursery stock is selected and prepared for export. There is of course danger that the moth mat be aceidentally disseminated in this comntry by Nassachusetts nurserymen, - a danger which we believe they will carefully guad against, as they lave been fully advised conceming the matter by our efficient State Nursery Inspertor, Dr. H. 'T. Fernald.

* Kirklaud, Report Massachusetts Horticultural Society, 1902. 


\section{THe Brown-tall Moth in Europe.}

The original home of the brown-tail moth is in Europe, where it oceurs over the entire country except in the extreme north. Altum ruotes speyer to the eflect that it is "distributed over the whole of eentral and southern Europe, extends into Algiers on the south and to the Ilimalayas on the east. The polar limit is in Sweden at $57^{\circ}$, the equatorial in the Inimalayas at $34^{\circ} . "$ Kirby states that it is " common in central and southern Europe, north $A$ friea and western Asia, but is a local insect in England." The moth has alwo been doubtfully reported from .Japan. This wide distribution is significant, as indieating the ultimate probable range of the inseret in the Lnited states.

The literature of the brown-tail moth is as old as the litcrature of ceonomice entomologry. When mam began to record his troubles with the pests of (ropes, this insect was amoug the first to reecive attention. The remarkable ontbreaks of the caterpillar's in certain years areated astonishment as well als alarm. Being clearly out of the established order of things, they were regarded as a punishment for human shortcomings: and as Divine interposition seemed to ofler the only remedy, it. was freely invoked to stay the plague. 'Thus in 15.8, duriug an outbreak of the brown-tail moth, a member of the city council at firemoble introduced a resolve begrging the local ehumels official " to excommunicate these peste and censure them, in order to check the damage they were doing daily." To the aredit of the comneil, let it he added, the resolve was promptly anated. In the sime contury, Chorier", a historian of Datupling re rates that these "aterpillams wereso abundant that the attorney-general of the provinere found it neersaly to issue an injunetion angunst them, and ordered them to evanuate the fields where they were feeding. Such records as these testify strongly to the arly damage by the mothe and the luelplessiness of the tammers of that day in the face of the eaterpillar ontbreaks.

Goedart, writing in 1635 , deseribes the "singular nature" and "remarkable knowledge and foresight" of the caterpillars in preparing their winter shelters. Madam Merian de- 
seribed the habits of the moth in 1683, and Albin in 1720 . In 1731, Reanmur, travelling fiom Tours to Paris, "found every oak in possession" of these aterpillars, and later made very complete studies of their habits. Roesel, in 1746, mentions and describes the moth. Linnaes described the moth in his "Systema Natura," Vol. 1., p. 502, 1758, and gave it the scientific name Bombyx clerysorlhoee. The genus Bombyx of Linneus has been divided by later entomologists into a large number of genera, based on structural charaeters; and this species, forming the tyje of the new genus Euproctis, is now known by the scientific name of Enproctis chrysorrhae (L.). Since the time of Linneus the browntail moth has been figured and described by nearly every entomologist who has written on the moths of Europe, and more or less complete aecounts have been given of its life history and habits.

Geoffroy, in his "Ilistoire abregee des Insectes," Vol. II., p. 117,1762 , in writing of the brown-tail moth in the vicinity of Paris, says that it is the most eommon of all caterpillars, and is found on almost all trees, which it often entirely defoliates in the spring.

In 1782, William Curtis published an aceount of the depredations of the brown-tail moth, in which he informs us that at that time " the inhabitants of London and its vieinity were thrown into the utmost consternation "at the hosts of caterpillars of this species, that completely stripped the trees and shrubs of their leares for miles in many places. The general appearance was such as might well eause alaum : for plants, hedgess and " whole plantations of firut trees, as woll as trees of the forest, shared in the general havoe, presenting their leafless branches in the midst of summer as though stricken and destroyed hy the blists of winter. An appearance so extraordinary was calculated to create terror ; it was naturally interpreted as a visitation from heatren, ordained to destroy all the sources of regetable life, to deprive man and eattle of their essential food, and finally leave them a prey to fumine" (Donovan). The alarm of the public was so great and prevailed to such an extent that prayers were publicly oflered in the churches to arert the calamity. Be- 
lieving, doubtless, that in emergencies works are as nocessary as faith, the town fathers oflered a shilling per bushel for the caterpillar webs. These latter were cut off and burned "Inder the inspection of the chureh wardens, overseers or beadle of the parish : at the first onset of this business, four seore bushels, as I am credibly informed, were collected in one day, in the parish of Clapham" (Curtis).

Olivier, in 1790, mentions the insect as very common in the neighborlood of Paris, where it feeds "indiflerently on all fruit trees and on nearly all other trees; one finds them as frequently in the forests as in the frardens."

Writing in 1803, Haworth, "I eppidoptera Britannical," p. 109 , states that "the caterpillars of this insect have sometimes become so exceedingly mumerous as to do incredible damage to the regetable kingdom," and refers to the historic outbreak at London in 1782. Donovan, in his "British Insects," Yol. XVI., pp. 39-45, 1813, gives a grood general account of the habits and damage by the insect, and quotes freely from Curtiss pamphlet on the moth, - a work that has now become rery rare. Bechstein, in "Forst u. .Jagdw.," 4 th, $2 \mathrm{Bd}, 1818$, describes the moth under the name of "white thorn spinner," from its habit of attacking this shrub. He writes: "It is said that these caterpillar's have devastated whole areas of forest, particularly oak wood lands. They are most injurions in the fruit garden." He notes that the caterpillars "in the spring gnaw the buds, blossons and leaves, and strip even the second crop of leaves from the tree. They also destroy the fruit, and make the tree sickly through sap exhiustion."

J. B. Godart, "Mist. Nat. des Lepidopteres," Vol. 4. p. 273, 1822, comments on the law which required French property owners to (lear their trees of the winter webs, and expresses the belief that a better plan would be "to destroy the elusters of egras immediately alter they are laid," - a method which is of course wholly impracticable where large trees are infested. I3lumenbach, 1825, considered this insect "one of the most destructive caterpillar's to fruit trees;" while four years later, 11. Wallner", "Ann. Soc. Ilort.," Paris, Vol. 4, found the caterpillars causing severe damage through- 
out Bohemia, Austria, Bavaria and Switzerland, and urged the importance of destroying the mature moths.

Rennie, "Nat. Hist. Insects," p. 266, 1830, tells us how the young caterpillars feed in ranks on the leaves; "the heads of each rank being generally in the same line, they all adranee simultaneously, and their progress has very much the appearance of a regular military movenent." He gives as food plants the elm, white thorn, black thorn, oak and fruit trees. In 1832, Boisduval, "Coll. Icon. des Chenilles d'Europe," records the caterpillar as extremely common, and doing "much damage to fruit trees, which are often stripped of their leaves." He points out the wisdom of destroying the winter webs in good season, before the eaterpillars emerge, by burning them from the trees. I gain, in his "Entomologie Horticole," 1867, he states that this is the most common insect in France, and that it lives on all kinds of fruit trees and on neirly all forest trees.

Ratzeburg, writing of this insect in Germany, in 1840, says that it is distributed over nearly all Europe, and is known everywhere as a pest both in the forests and orchards, where it often destroys the entire fruit crop and injures the shape of the trees. It frequently occurs in the forests in multitudes on the oaks, willows, elms and other deciduous trees, entirely devouring the leaves and blossoms. Writing at a subsequent date, he states that in the late 50 's the eaterpillars ravaged the oaks in the streets of Potsdam, and even killed some of them. Brehm and Rossmässler, in their "Thicre des Waldes," 1867, write of the moth as being more injurious than certain allied species, and emphasize the need of web destruction. These authors consider the browntail moth as being "more injurious in the fruit garden than in the forest." Figuier, "Insect World," 1868, describes how the caterpillars have ravaged "the plantations of the promenades of Paris." Blanchere, "Ravageur's des Forets," 1876 , writes pertinently of the folly of negleeting the destruction of the winter wobs, his observations being as applicable to American as to French conditions. Of the apathy of the average property owners he says: "Thus they delay or neglect the most simple precultions up to the 
time a real invasion takes place, or until the frightful damage arouses their attention. Then the public clanor warns the loeal authorities. It disturbs then, and the government sends savants to observe the spread of the phenomenon, and at the same time to invent a remedy for this neglected evil. But the savants, ariving unfortunately in the midst of a bona fide outbreak, do nothing : for there is nothing to do, and the insignificant remedies attempted are too late, or amount to nothing. It is not during the time of serere epidemics to combat this pest, it is by an application of practical methods, established and followed carefully and patiently during many years." Writing in 1881 , Altum, "Forstzoölogie." Vol. 3, p. 106, states that the nests of the moth were very abundant in the vieinity of Eberwald " in 1sit75, on isolated fruit trees, ehiefly pear, the latter being thickly infested. . . On older fruit trees there were ats many naked branches as there were nests." In northern Germany "they are the ehief plague of young oak forests, oak plantations, and particularly the lower-growing oaks." In Brehm's "Tierleben," Vol. !, ls!1-2, Tasehenberg has written: "These "aterpillars are in the first rank of those which atleet our fruit trecs, and not unfirenuently through enormous outbreaks is shown the "harmeter of the incrensable neglect of the orehardist who during the winter or arly spring could so readily cut ofl and burn the easily found caterpillar nests."

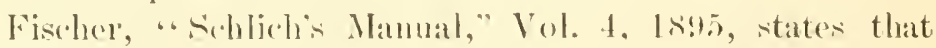
" in the Berlin Koölogreal ciarden they [the caterpillars] destroy the follage almost erery year." With reference to destroying the caterpillats he salys: " ( are must be taken to protect the hands against the hairs, which canse inflammation." This dantage at Berlin is also mentioned by an anonymous writer in "Gartenflor:1," p. $3600,18 ! 7$, who says that the caterpillars" "this spring . . Mave entirely stripped the oaks and many bushess in the \%oölogical Garden as well as in the Botanical Garden." These references, taken from the rast mass of foreign writinges on the brown-tail moth, show how woll the insect is known, and what a formidable pest it is at home. 



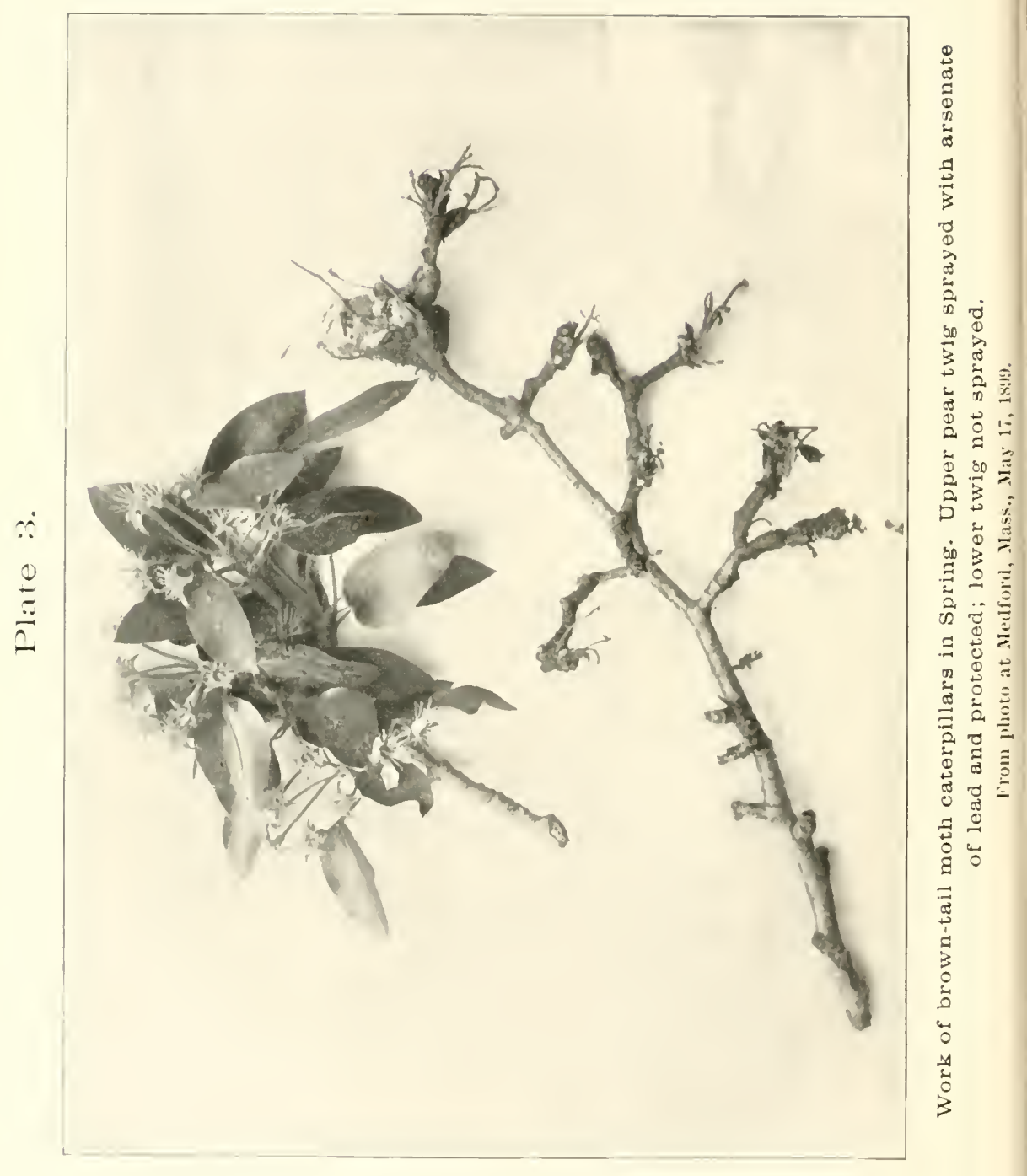


THE 18977 () OTHBRAK.

The 18.97 ontbreak of the brown-tail moth was a localized one, but made up in severity what it lacked in extent. I circle of two miles in diameter, with eentre at the depot on Park Street, and including parts of Somerville and Cambridge, would contain nearly all of the derastated area. It Malden, Everett, and more particularly at Medford, there were small infestations, mainly of importmee as indicating that the spread of the moth ontward from the central colony had already begun, and aflording insects for the infestation of new territory. In the central district the devastation was almost eomplete. The pear and apple trees, on which the majority of the winter webs had been spen, were first stripped. Such remarkably large numbers of these insects were harbored by these trees that their leaf supply was soon eonsumed, and the half-grown caterpillars were forced to migrate in search of food. In this migration shade trees suffered as sererely as fiuit trees from the attacks of the insects. Willows, elms, maples and lindens often were completely defoliated. In their mad search for food the insects swarmed along fences and sidewalks, making the latter slippery with their crushed bodies, and even entered houses. Rose bushes, grape vines, garden erops and even grasses were consumed by the hungry insects. By the middle of . Tune the trees in the central infested district appeared as if swept by fire, the damage, so fur as it went, being as serere as any caused by the gypsy moth.

This outbreak of the moth in 1897, now historie, is entitled to more than passing mention, since the seenes there cnaeted will doubtless be repeated many times as the moth spreads into new territory. In fact, such an outbreak is often necessary to aronse the average eitizen from his apathy toward the eare of trees, and make him see the wisdom and necessity of stamping out this particular pest wherever it occurs in any considerable numbers. While the detaits of the swaming of the caterpillars in 1897 are still well remembered by those who suffered from the moth, statements made by property owners soon after the outbreak are of 
special interest, and we reproduce a fow of them, to give an adecpuate idea of the real significance and importance of this new lest of fruit and shade trees.

\section{statements fiom C'itizens.}

Mr's. ('. I). ('hawe, is I valoo Street, Somerville, say's:-

We first noticed the brown-tail moth caterpillars in 1895 . They were so close together they looked like brown fur. We foum them on the trees and fences, in the honse, and even fonnd their cocoons on the winctow screens. In 1897 they were so thick we eould not go ont of doors without getting them on our clothing. The front of the house and the pear trees in the garden were corered with them. 'That summer the pear trees looked as if a forest firc had swept orer them. The second brood did not seem to trouble us as much as the first. For the past two years we have not had any fruit; the trees blossomed this year, hut the fruit dropped off.

Mrs. E. E. Bailey, 21 Medford Street, Malden, writes:-

I have lived here six years, and never noticed the moth until 1898. We did not have it in 1897 . The pear trees were the only ones tonehed, but the eaterpillars ate the leares off from them. The leaves eame out again, and there were some blossoms, but they did not blossom as they would if the leaves had not been eaten. Then the caterpillars eame and ate the trees bare again, so that they looked as they do in winter. We did not get a bit of fruit from any of them this year. The house was eovered with these caterpillars, and they even eame into my kitchen. I had to gather them up and burn them. I used to sweep them up by hundreds and burn them with oil.

Nicholas Fleming, corner of Kent and Beacon streets, Somerville, says: -

We first noticed the brown-tail moth two years ago (1896). We got no fruit that year, and we have not had a pear this year. 'The stripping did not seem to kill the trees, they leaved out again. My sons spent all the spare time they had in picking off the eaterpillars and killing them with kerosene. This summer the inseets bothered us considerably in the apple trees. The currant bushes were eaten both years. A small grape-rine was bally eaten, and 
the eaterpillars also attacked the peach tree. For two years we have had almost no fruit. This spring the boys took off the nests and trimmed the trees, and that has saved them.

Vincent L. Kelly, 33 Park Street, Somerville, writes:-

We first noticed the brown-tail moth in May, 1897. 'That year we had no fruit, and we have had none this year. The trees were entirely stripped (1897), but came out again later. Some time about the middle of .Ime the caterpillars began to disappear. While they were with us they were a most disgusting sight. They elung to the outside of the house and piazza, and some even'got into the house. We tried killing them hy picking them off the fences, etc., and putting them into kerosene; but we conld not aceomplish much, as they were so numerous.

Mrs. Peter Mooley, 41 Ivaloo Street, Somerville, says :-

We first noticed the eaterpillars, in 1897 , and we could do nothing with them. We had to take hrooms and sweep them away from the doors. They ate the leaves off the trees, so that we did not get any fruit that year or in 1898. The caterpillars seemed to come all at onee. We were all poisoned with them. The houses were full of them. They were a sight. They were on everything. - fenees, shrublery and flower bushes. The place was fairly alive with them. They were even in the bed-rooms. We tried lime and salt, but nothing seemed to check them.

Mrs. H. F. Williams, 213 Beacon Street, Somerville, states :

The caterpillars were rery had in 1897 . They would have stripped the trees if we han not fonght them: even then they damaged the trees. In spite of all we could do, they erawled all over the house, up to the door, and even got into the house. They seemed to be everywhere. We burned them to get ricl of them. They did not destroy our trees, but it was only becanse we attended to them all the time. They wonk have eaten the trees in one night, if we hat not kept them down. The trees did not bear at all this year (1898), and we have had no fruit but cherries. The caterpillars ate everything that came within their reach, - rose bushes, geraniums and plants. Nothing was free from them but the grape-vines. They were not so numerous this summer as last. All the nests were supposed to have been taken 


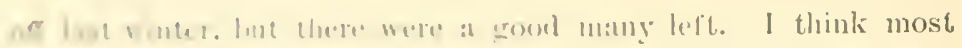

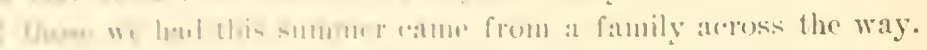

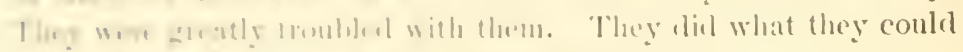
t.

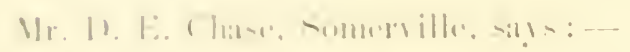

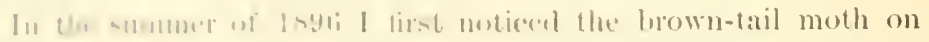

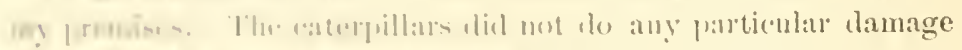

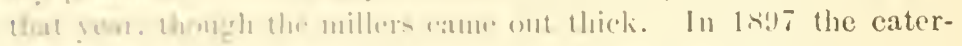

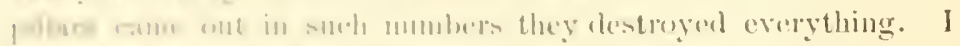

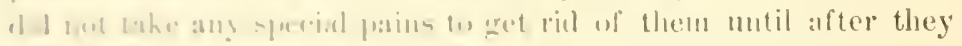

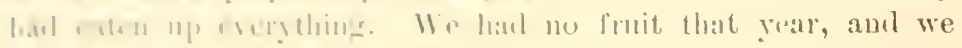

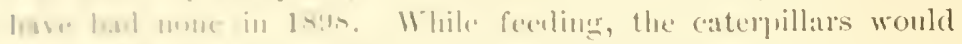

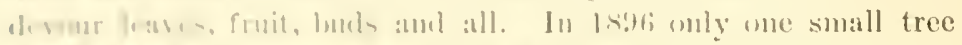

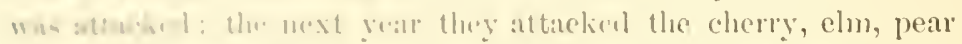

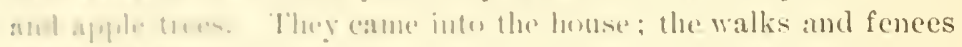
wreale, and met with them. For there or four alas I went out 1, n morsing and - wept them off the jlanks. Iast winter I cut

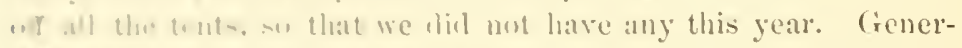

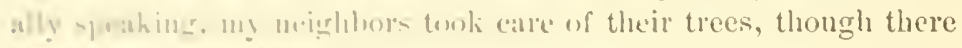
not, a fo 11 who inl not.

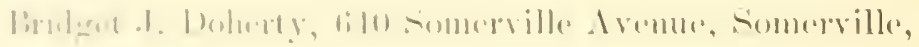
1) 4 ;

In $1 / 13,14 ! 7$. thu Inown-tail Imoth raterpillars eame ont in

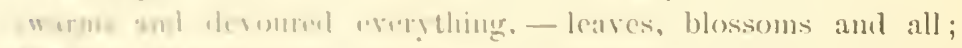

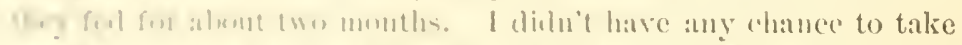

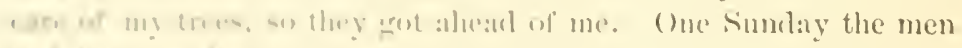

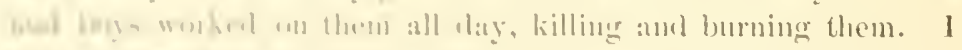

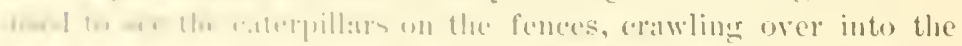

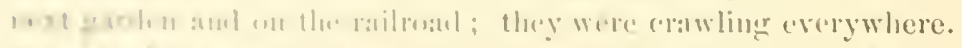

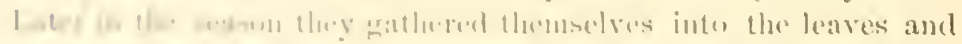

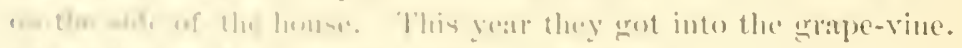

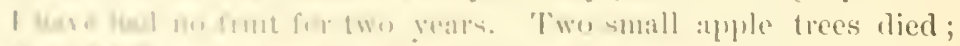

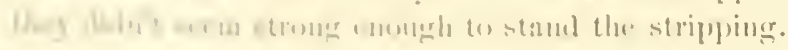

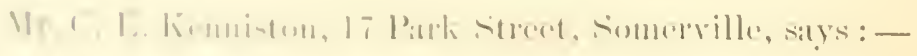

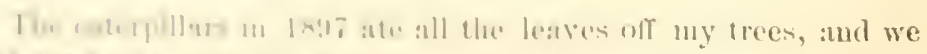

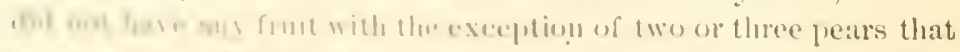

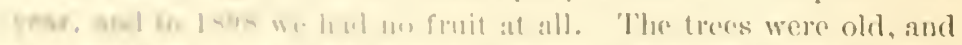

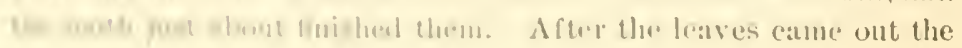




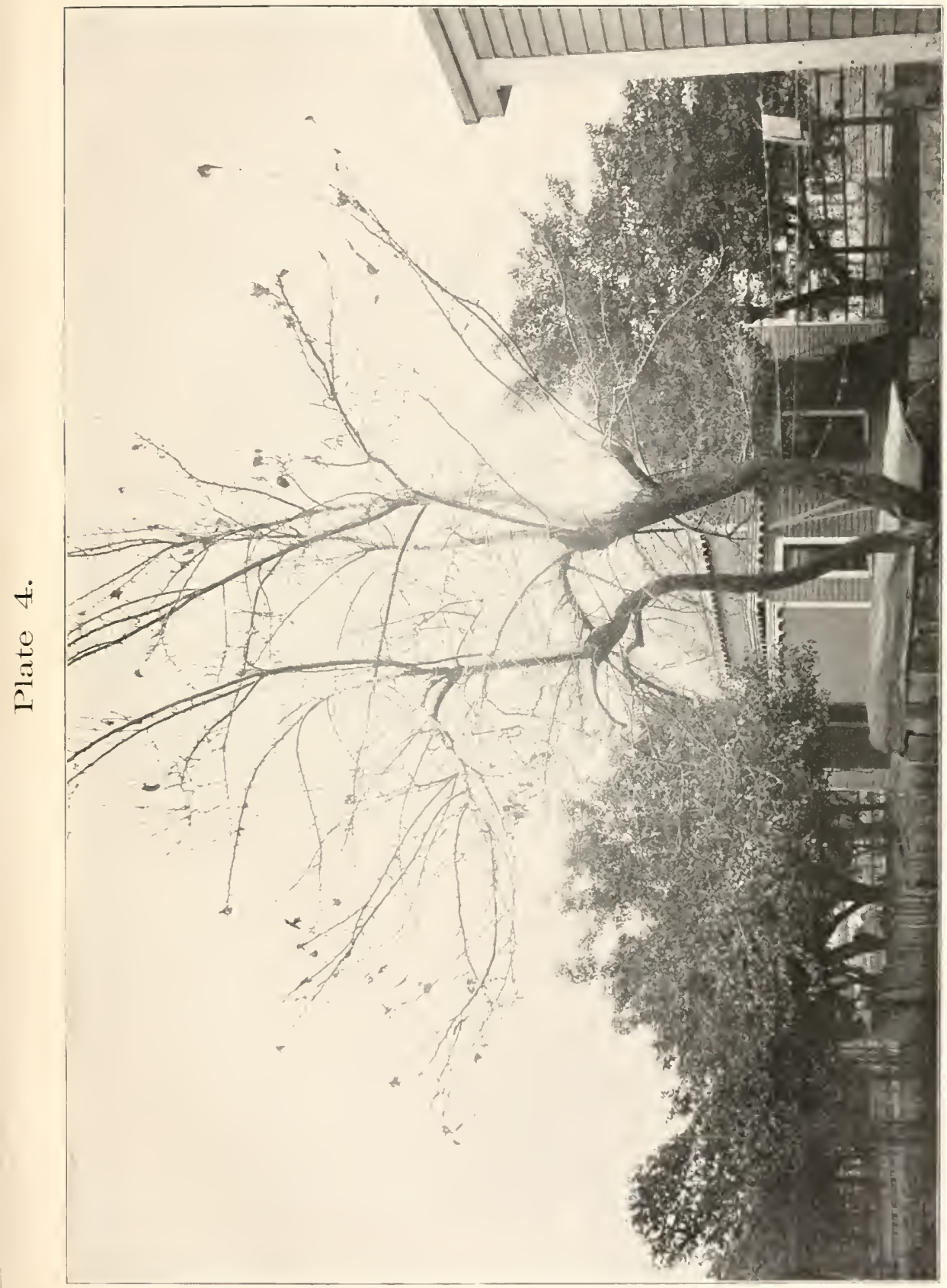

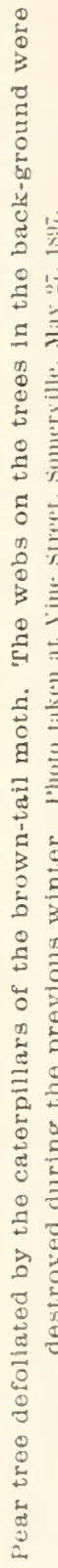



trees suddenly looked as though they hat been burned by fire. 'I'hat summer all the foliage around here seemerl to he scorehed. I would leave home in the morning, and the trees would be budding out; the next day they would be stripped clean. 'The caterpillars were all around the louse, on the fence and even in the house. I could not go into the yard without having them drop, on me from the trees. I think the lmown-tail moths are worse than the gypsy moths.

Mrs. J. Iseland, 377 Washington sitreet, somerville, says :-

'The brown-tail moth eaterpillar's came in large numbers; they stripped all of om trees. My son got the nests off some of the trees, but the trees he was not able to elear were just eaten up, and we did not have any frut. We had no fruit to speak of for two years, except on one tree which was right near the honse, that we were able to keep clean of nests. 'The insects were very destructive. I think they killed my strawberry plants. My rose bushes were somewhat eaten, too. I'hey ate the elms across the street, and then came over to my rose bushes. Wre laal a second crop of the caterpillars. They ate the leaves on glape-rines, pear and apple trees. I think they are the worst creatures I erel saw. We could not sit in our garden without having them crawl all orer us. They will even eat the regetahles growing in the garlen; they ate the beet tops and cabbages. I think they are much worse than the gypsy noth, beeause they increase so fast. 'liere are cnongh caterpillars in one nest to cover a whole tree, and there will be a dozen or twenty nests on a tree.

Mrs. J. A. Kincaid, ss Vine Sitreet, Somerville, Writes:-

We first noticed the bown-tail moth in 1897 , when they stripped the trees so that they looked as though they had been bumed. They stripped them twice that yeal. We have not had an apple OI a pear from them since. 'They blasted all the rose buds we hat. We wonld have been satistied if they lat taken the rest of the pear trees, for they are now no goml. A few came into the house, perhaps two or three. and we fomd one in the bed. 'Tlue caterpillars eame in lhores right down the driveway. I am not exaggerating when I say that our fenes and the gate posts were so covered with the eaterpillars that they looked as though they were covered with fur. We poured kerosene oil over them, and had to keep that gate elosed all smmmer, beeanse there was a tree near it 


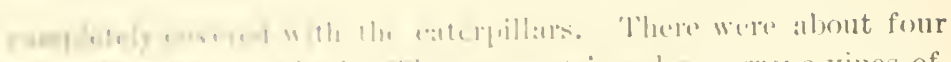

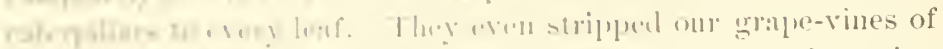

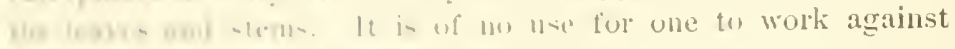

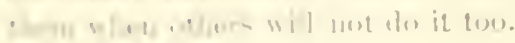

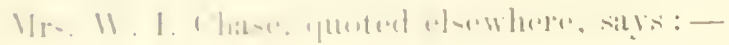

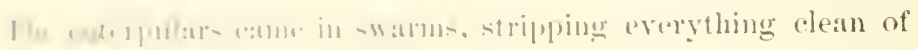

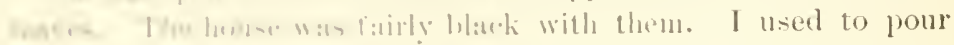

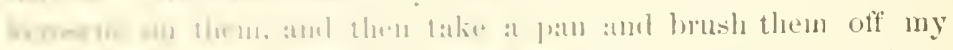

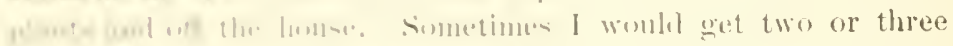

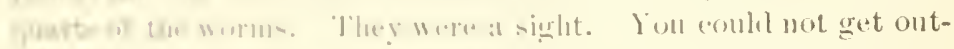

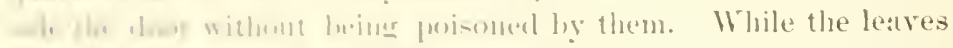

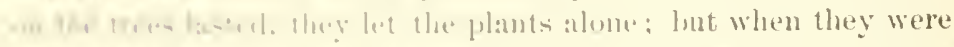

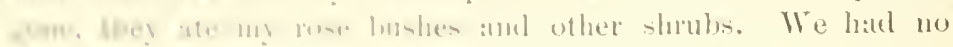

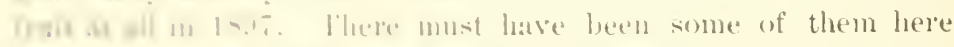

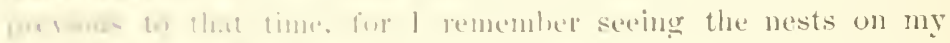

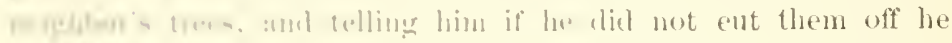

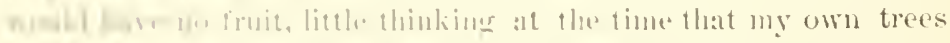

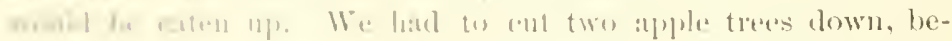

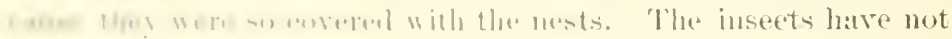

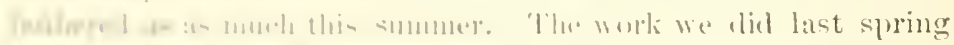

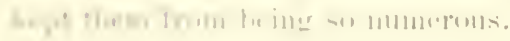

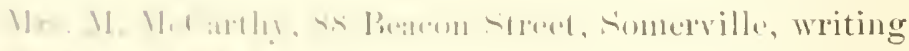

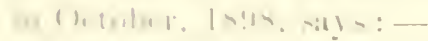

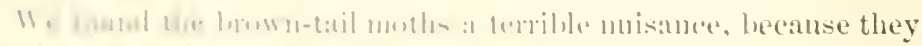

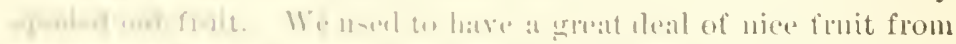

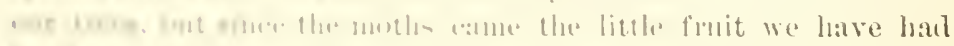

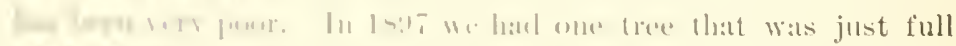

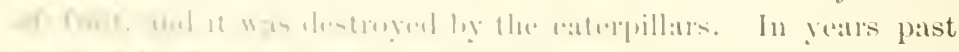

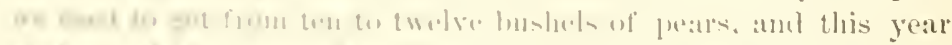

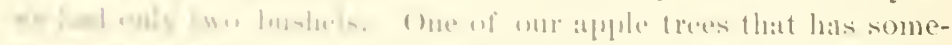

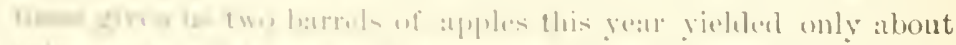

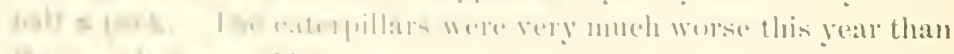

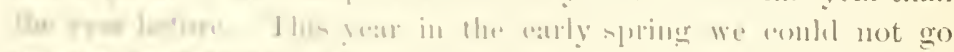

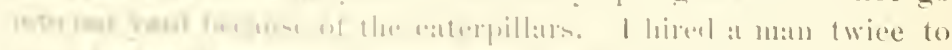

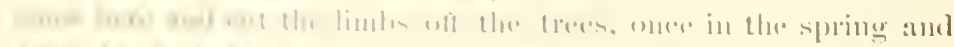

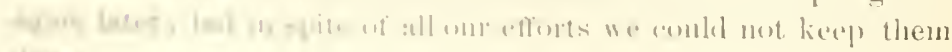
$1+=11$

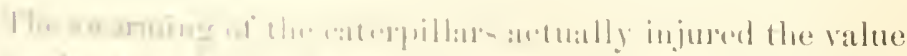

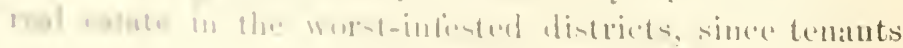


would not lease property so located, while those ocenpying houses near which the atepillars were abundant often were forced to vacate the same. Mr. L. L. Tower, of the "TowerCutter Company, Boston, writes us:-

The year before the brown-tailed moth appeared in my pear orchard at Somerville it produeed orer two hundred bushels of pears; the next year the eaterpillars were on the trees by the bushel, and I did not lave a pear that or the following year. The damage by the eaterpillars was a great annoyance, not only to my tenants but to the neighbors. As a eonsequence, iny tenants moved out and left the house vaeant for about a year.

Mrs. E. Gibson, 72 Beacon Street, Somerville, says:-

We were all badly poisoned by these moths. We did not know that they were here when we took the honse, and so we have had to bear the consequences. My husband spoke to the owner of these premises, and told him that unless something was done we could not stay. He said he knew they were drealful things to have around, but did not seem to be able to do anything. The trees were eaten up by them, and we had no fruit whatever. 'They troubled us more or less all summer. They seemed to be worse here than anywhere, but all our neighbors were troubled with them and tried to get rid of them. The trees and grass were covered with them. We nsed to take hrooms and try to sweep them off the piazza, and we had to guarl against their getting into the house. 'They were a regular plagne.

Mrs. Alexander Garboti, 160 Park street, Sonterville, says :-

The first time these eaterpillars tronbled us was in 1897, and then they were terrible. Everyone abont here eomplained of them. 'They were not only outside but inside the housc. I found them on my pillows. One of my tenints moved away on alecount of them. My tenant who lived up stairs conld not open her windows. The caterpillar's were all over her piazza, and she could not sit there beeause of them. She would brush the caterpillars up with the broom into a good pile, and then call me to look at them; and I would have to hold the pan while she swept them up, and then we carried them to the bank yand and humed them. This was very bat for me, and poisoned me dreatfully. My nede wats all swollen up and reel with at rash. 
The testimony of such witnesses grives mnquestioned evidence of the damage eaused by the moth. A large number of statements exually interenting and of the same general tenor have been onitted, as being only corroboratory. Public interest in the moth was most intense wherever the insect had appeared in foree: trees were devastated, garden crops destroyed, and dwellings swamed with the eaterpillins: while to the grpsy moth rommittee and their employees went forth in no uncertain tones the Macedonian ery, " ("ome orer and help) us," - an anpeal to which the committee did not turn ad deaf" earr.

The 1897 outbreak was novel and even alarming, hence property owners observed the cateppillatrs more closely than in later years; yet earh year since in sections where the motl has been necrlected the same devastation of trees, the sanc migrating of lungry eaterpillars, the same injury to human beings, has occurred. Wherever web destruction at the proper time has been properly earred out, either by individunls or municipalities, a notable legree of freedom from danage by this insect has been secured.

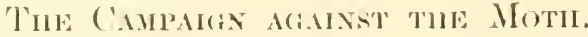

As soon as the identity of the brown-tail moth had been settled, the infisted district was thoroughly examined by Mrsirs. Fermald and Kirkland, acempanied by President II. I1. Goodell of the IFuth lixperinent Station of the Massaclusetts Agricultural college. Aplureciating the gravity of the situation, President (iondell authorized the preparation of a special bulletin on the inseret, which was published by the Iatch kxperiment Station in Iuly, 1897 , and generally distrihuted in the metropolitun district. The presence of the moth wats also bremght to the attention of IIis Excellaney the late Governor lioger. Woleott, by the following lottre from the wylsy moth committer and the director of the Experiment station:-

IiosTon, M:ty $25,1897$.

His Excellency Rogen Wor.cotT, Governor of the Commonwealth.

Sul: - We desire to subuit for your consideration the facts relative to :mother inseet pest which has appeared for the first time in this Commonwealth and in the United states. 
Plate 5.

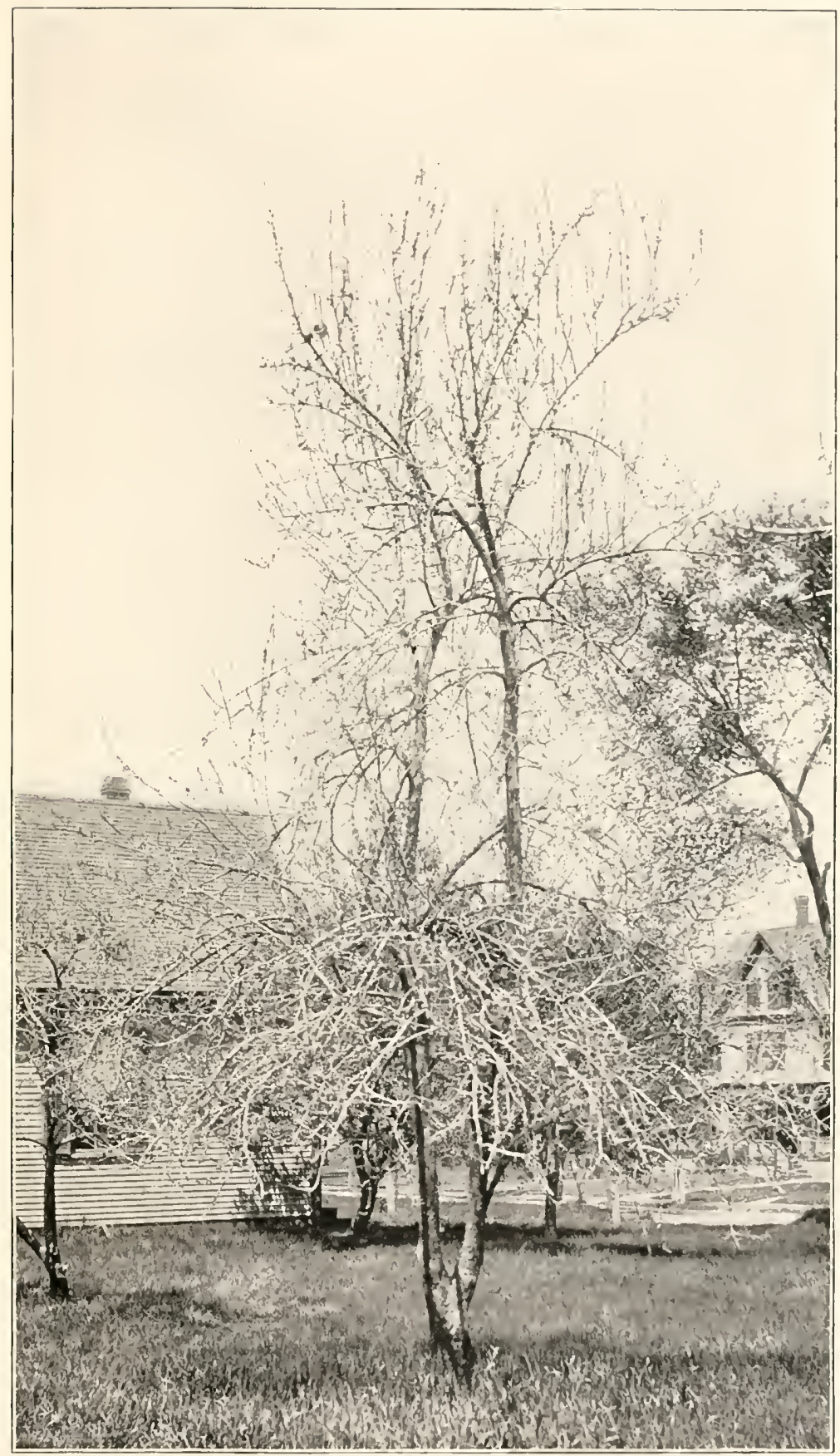

Pear tree stripped by brown-tail moth caterpillars,

Medtord, Mass, May 17, 1899. 

It is commonly called the brown-tail moth (Euproctis chrysorrhoea), and is so destructive in its habits, having so wide a range of food, that in European countries it is one of the few insects for the suppression of which laws have been enaetel.

The centre of the infested district in this State appears to be in Somerville, thongh how widely the inseet is dispersed we have been mable to determine in the short time intervening since its appearance. In an examination of the district by our entomologist, Prof. C. II. Fernald, and Dr. L. O. Howard, chief of the Division of Entomology, Department of Agrieulture, Washington, D. C., the insect was found feeding on the pear, apple, cherry, strawberry, raspberry and rose hushes. The trees were entirely stripped of their leaves, and the trunks, fences and sidewalks were swarning with the caterpillar's.

The side of a honse in the vicinity was corered with them, and they had even pushed their way into the interior. The most seriously affected point is immediately around the depot and railway tracks, inereasing greatly the risk of dispersion.

The caterpillars are just finishing their feeding state, and will soou go into the pupa condition. The time to attack them is now, by eontact insecticides, and in the late summer when they emerge.

Dr. Howard, govermment entomologist, now here inspecting our work on the gypsy moth, has kindly eonsented to give the benefit of his atrice.

To meet this sulden emergeney, a speeial appropriation of $\$ 10,000$ from the Legislature seems absolutely neessary, and we therefore beg Your lixeelleney to take sueh steps as seem in your judgment best.

\author{
E. W. WoOD, \\ Avalstus Pliste, \\ S. S. STlitson, \\ Joms (7. A A ERT. \\ F. W. Sabilixt, \\ WM. R. Sissioxi, \\ Committee of the Boarll of - Iyriculture \\ on Ciypsy Moth, Inseets and Birds. \\ HeNRY II. GoOplat, \\ Director IIatch Experiment Stution.
}

The matter was also presented to the Goveruor orally by the gypsy moth committee, Messis. Fernald and Kirkland, with Dr. L. O. Howard, entomologist of the I'nited States Department of A griculture, who fortunately was in Boston at 


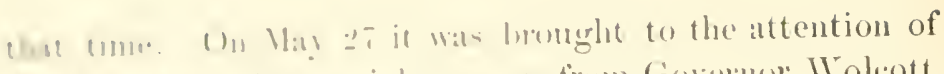

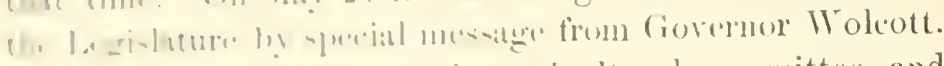

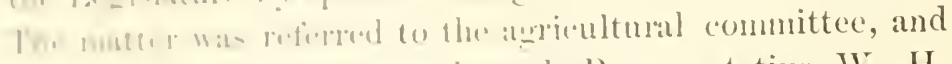

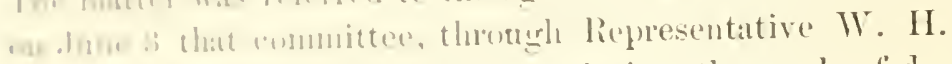

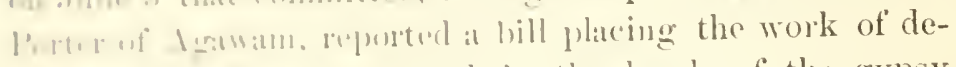
th ying the hrom th-til meth in the hands of the gypsy

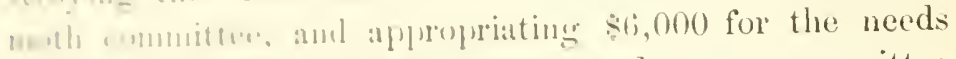

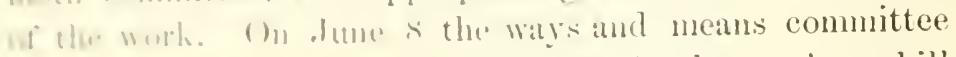
re reted atrenly un the hill. Iater in the session a bill

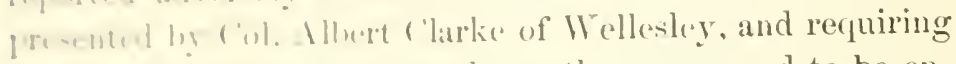

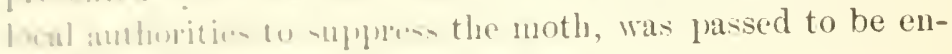

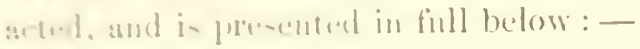

[1'HA)THA 5IR, A'TS OF 18!17.]

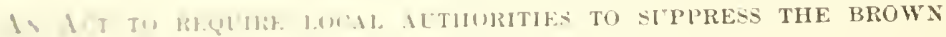
T. II. YUTII.

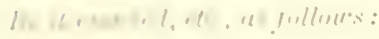

-11 ind 1. Whenevele the pest known as the hrown tail moth

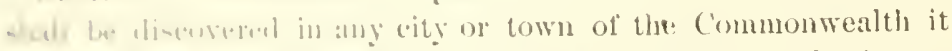
4half lie the ifuly wi the rity or tows govermment to take imme-

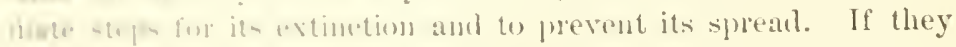

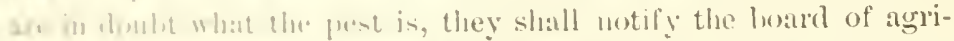

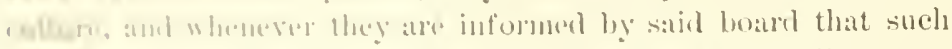

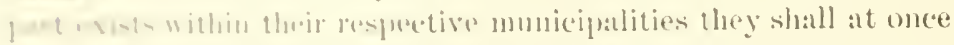

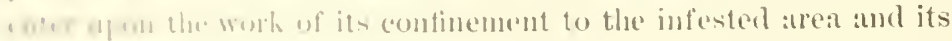

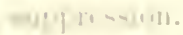

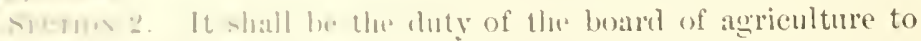

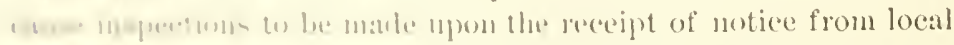

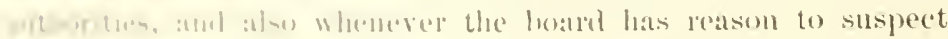

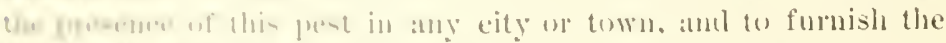
I I antarias an ample supply of printed directions as to the

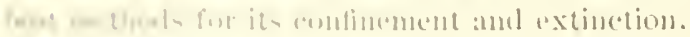

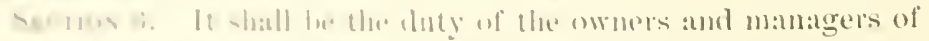

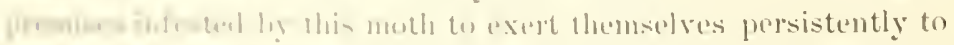

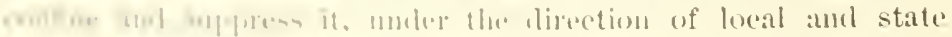

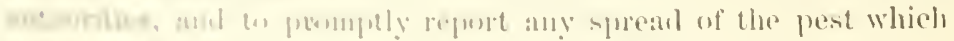
1.

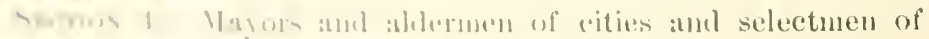

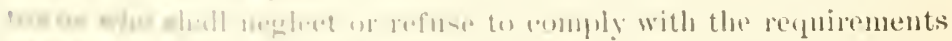

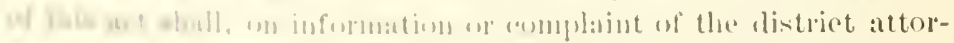

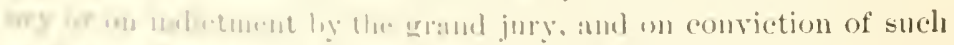

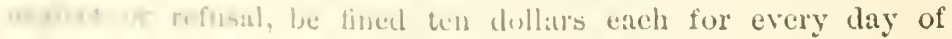


such neglect or refusal after the receipt of due notice from the board of agriculture that thoir city ol town is thus infested.

Section 5. 'The owner or manager of any infested premises who shall, after the receipt of a notice in writing from the mayor and aldermen of his city or from the selectmen of his town, or from the board of agrieulture, neglect or refuse to eomply with this act, shall upon conviction of such neglect or refusal, before any conrt of competent jurisdiction, be fined one dollar for every day of such negleet, or confined in jail not more than five days nor less than one day, or suffer both peualties in the diseretion of the court.

Section 6. This act shall take effect upon its passage. [A proved Jine 11, 18.97.

In the mean time, the caterpillars were swarming in large numbers along the line of the Fitchburg Railroad at Somerville, and were evidently being seattered on trains. I few of the employees of the gypsy moth eommittee therefore were detailed to stamp out this pest spot, and this was done, the caterpillars being destroyed by spraying with soap solutions and kerosene emulsion. On June 24, 1897, the executive committee of the Board of Arriculture roted to advise the mayors of Somerville, Cambridge, Malden, Medford and Frerett that the brown-tail moth had become colonized in their respective municipalities, and urging then to take means to secure its supleression. It was also voted to spend a sum not to excend $\$ 150$ in examining towns thought to be infested. Is a result, it was found that the moth had already become widely dispersed. The result of the examination made in the fill of 1897 is given below: -

\begin{tabular}{|c|c|c|c|c|c|c|}
\hline Somerville, & . & . & 1,411 & Winchester, & & \\
\hline Cambridge, & . & . & 355 & Woburn, . & . & \\
\hline Mediord, & . & . & 149 & Charlestown, & . & \\
\hline Malelen, & . & . & 92 & Belmont, . & . & \\
\hline Everett, & . & . & 72 & Burlington, & . & \\
\hline Melrose, & . & . & 31 & S:tugrus, . & . & \\
\hline Stoneham, & . & . & 31 & Revere, & . & \\
\hline Arlington, & • & & 29 & & & \\
\hline
\end{tabular}

It is probable the moth was distributed elsewhere at the time of this inspection, which from lack of funds wats neces- 
mil! a limiend mon. Nowe or less activity was shown on

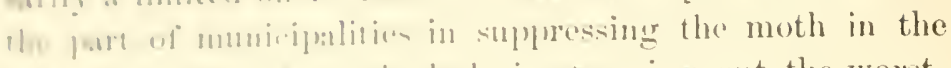

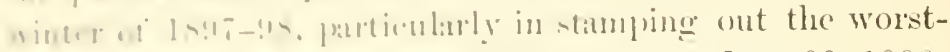

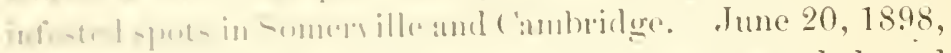

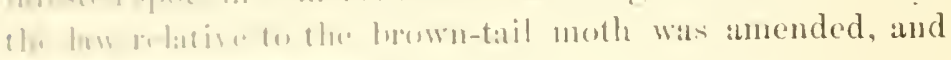

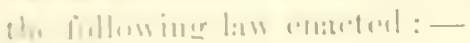

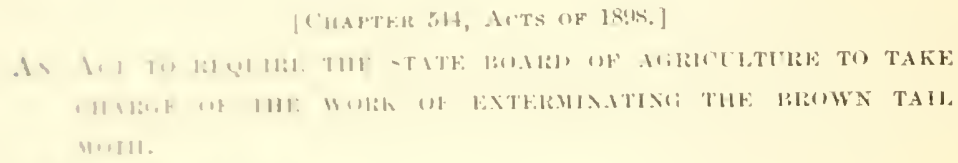

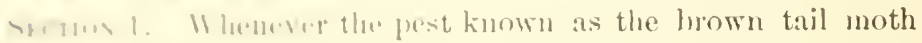

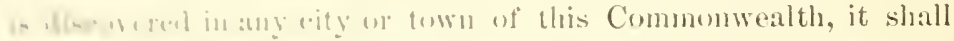

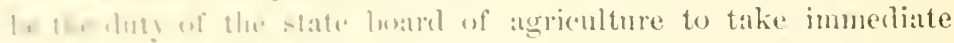

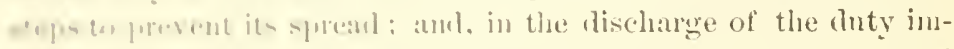

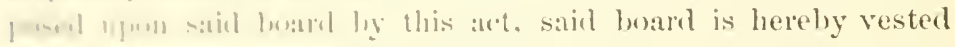

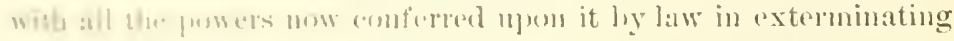
the sym moth, amb may expend of the money heretolore appro-

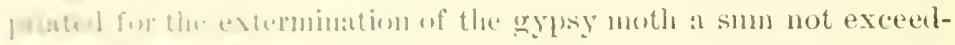

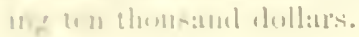

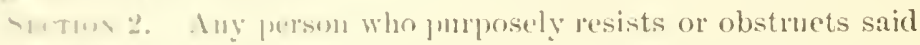

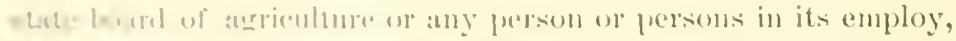

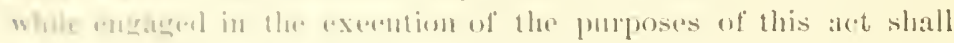

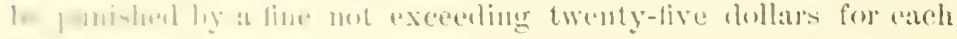
al. 1,19.

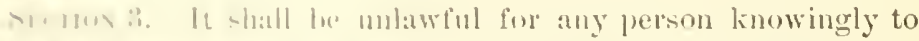

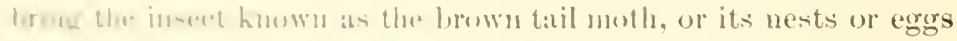

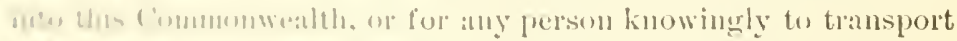

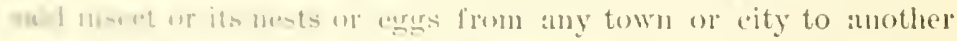

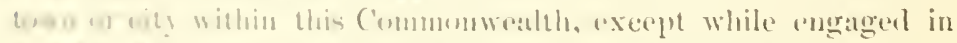

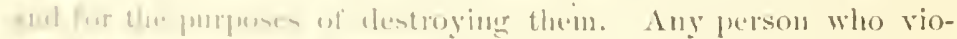

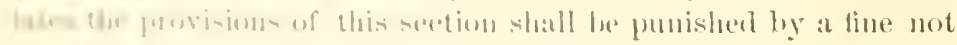

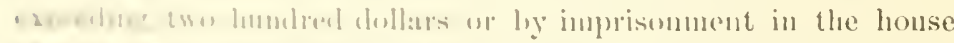

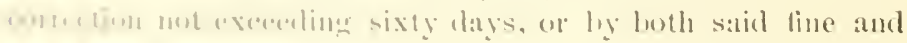

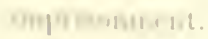

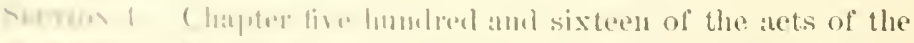

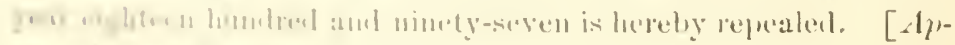
gumend, / Ine :21), Is!/4

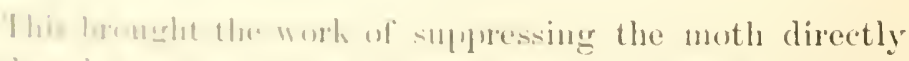

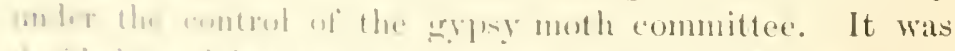

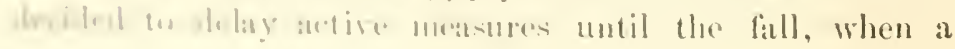


campaign of wob destruction was commeneed, in which large masses of webs, particularly in Cambridge, Sommerville, Malden, Medford and Everett, were destroyed, the sum of $\$ 9,998.96$ being spent in this work. Up to .Tam. I, 1899 , thirty-two cities and towns were found infested by the moth.

Work against the bown-tail moth was continued by legislative enactment with another appropriation of $\$ 10,000$, dedueted from the sum appropulated for work against the gypsy moth. This was ehiefly spent in web destruction late in the fall, the actual sum rexpended in this work being $\$ 9,999.81$.

During the year ls:9 the following work was aneomplished:

Trees inspected,

413,758

Trees sprayed,

Old winter webs destroyed, . . . . . . 13,519

New winter webs destroyed, . . . . . . 884,480

With the cessation of the State work against the gypy moth and brown-tail moth, in Febrnary, 1900, it became necessary for municipalities to enter upon a campaign a gainst the latter insect.

This work was taken up in good spirit by the worst-infested municipalities, and has been carried out to a ereater or less extent each winter since that time. ('ambridge, somerville, Medford and Iynn have been particularly atetive in destroying the brown-tail moth, and as a result these eitios have been quite grencrally exempt from damage by these caterpillars in the summer season. 'These operations have been largely direeted toward the destruction of the moth on street trees. Many citios have taken the broad - and it. seems to the writers entirely correct - view that the moth on private estates, if neglected, is a menace to the shade trees of the eity as well as to the property of other eitizens. Where this view has been held, the moth has been destroled on street trees and private trees alike: and, as a result of this treatment, cities like Semerville and Cambridge have gained quite a degree of immunity from the insect. Unfortunately, however, where cretain cities fight the moth in a 


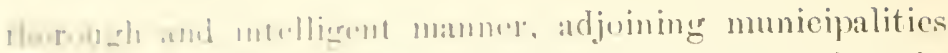

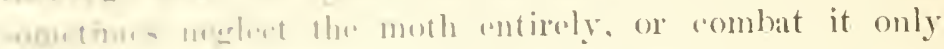

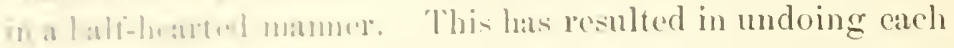

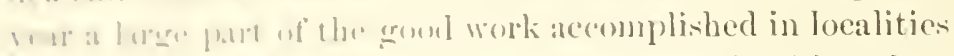

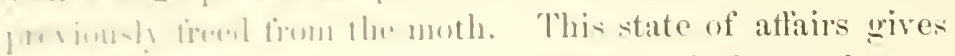

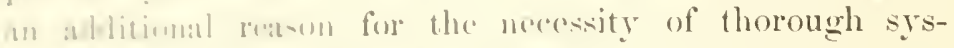

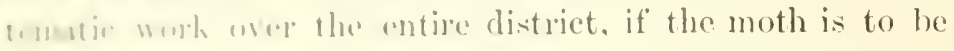
ㅂ.

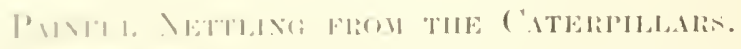

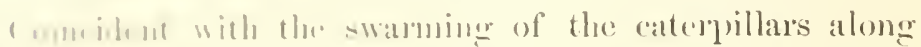

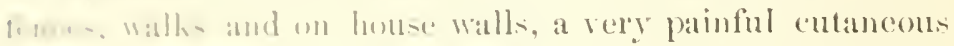

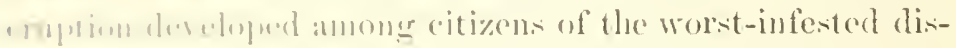

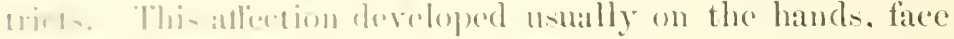

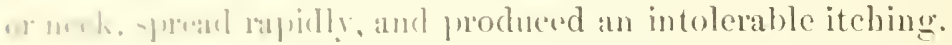
It liret the ratler of the trouble was not recognized by the lenal fuly-ician-and some anxicty was felt, at least on the

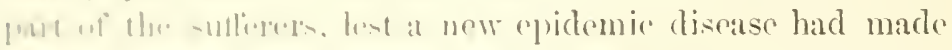

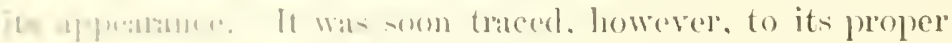

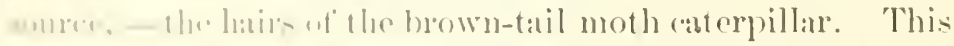

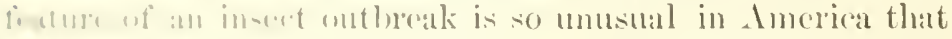
1 is worthy of fartionlat mention. Briefly stated, it was

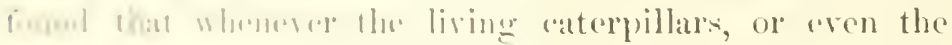

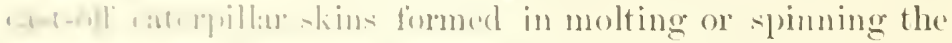

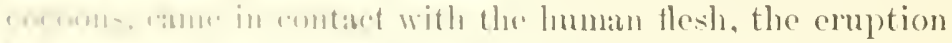

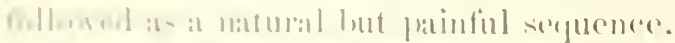

This m toline of the humbu skin by caterpillars is not an

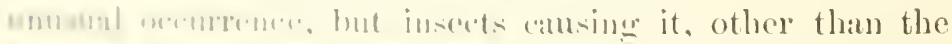

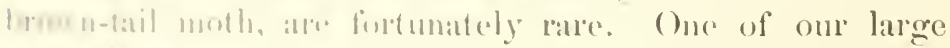

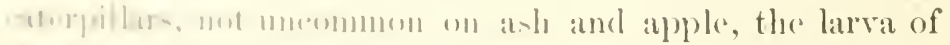

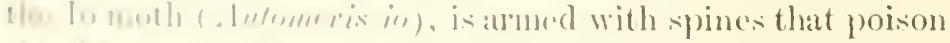
1. Whe while the situe holds true with the southern satl-

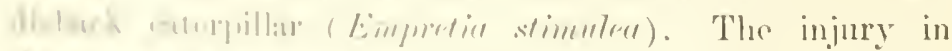

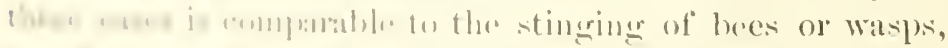

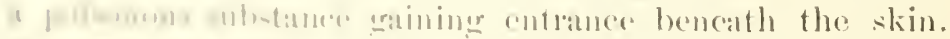

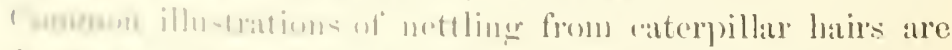
fout in the ato of the hickory aterpillas" (ITalesidote

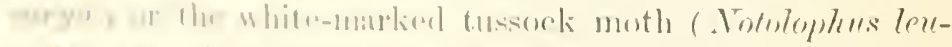

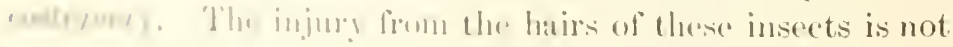


to be compared in point of severity with that caused by the hairs of the brown-tail moth caterpillar, which is of a peculiarly intense, burning charater. So far as known to us, no American insect can compare with it in this respect, although it is probably exceeded in severity by the urtication caused by the processionary caterpillar of Europe (Thanmetopae processionea).

In orchards where there are laree numbers of brown-tail moth cocoons, a light breeze is suflicient to wat the irritating hairs upon passersby, with most ammoying and painful results. In investigating the labits of these caterpillars in the field we were often severely nettled by the hairs, and can testify that the intense irritation lasts for sereral weeks. The principal sutierers from this feature of the caterpillar outbreaks are women or children, who by necessity or habit are often confined quite rlosely to badly infested estates. Among these parties the suflering frefuently begared description.

\section{Statements from sufferem.}

Mrs. H. F. Williams, 213 Beacon Street, Somerville, says :-

We were shockingly poisoned by the caterpillars of the browntail moth. They tronbled us all summer. Every member of my family was poisoned. At first we did not know what they were. My little boy could not go near them withont getting poisoned; every time he went to pick cherries he would come down from the tree badly poisoned. If my baby went near where they were, his face would break out into a rash. I was so dreadfully poisoned that I thought I had some frightful disease. My hands, face, neek, arms and limbs were broken out with this rash. Most of the caterpillars we hat in 1898 came from a neighbor's place. They came over the fence, into the house and eren into the closets. They would get on clothes hung on the line, and when these were worn they poisoned us.

Mrs. E. L. Bailey, 21 Medford Street, Malden, writes:-

I was badly poisoned on my neck and arms by the eaterpillars. At times I was nealy erazy with the itehing and irritation caused by the poison, and one of my ehildren was affected in the same way. 
Mr. J)anial L. ('hatse, a well-known somerville ritizen, la:s wittull w: -

My whole fandy suffrerd from poisoning hy these creatures, the skin heing so hadly imitated that we were obligerl to hathe in soxla water, salt water, cte. We felt the effects of the poisoning all smmmer. When my house was painted, the painters, in seraping moler the atres, stanted up the hairs of the eaterpillars, and we were thus all nore or less poisoned again.

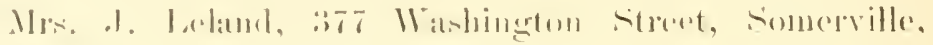
Nilyin: -

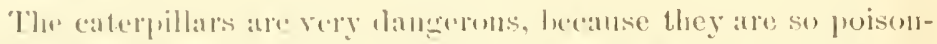

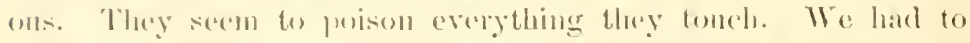
Wasl all regetahles hought in from the gramen. My son, who worken in the garden a rreat real, was bully poisoned; his neck was a solid mass of rash. The rest of the family were also poisuned in a less degree.

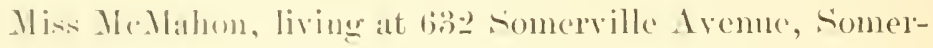
ville, silys: -

We first noticen the eaterpillars in 1897 . They were all over the trees. At the same time we hesan to have a drealful itehing, from which we suffered so much that wo were obliged to consult a plıgsician.

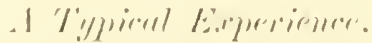

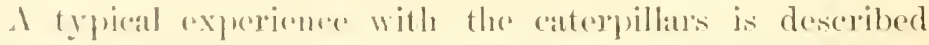

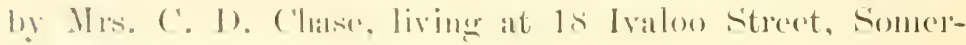
vill, :-

While roteing the limbe from the infested troes my lusband was bally poisoned, his eyes in partionlar heing afferted. In cleaning the wimlow scerens in the homse I was also hatly poisoned; the

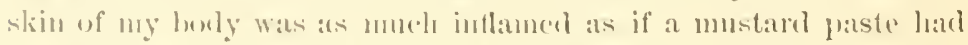

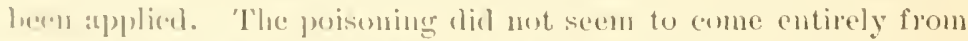
contace, lut the atil serened to be filled with something which ('ansed the iteling amb horning sensation. We were affected during the whole (wo nonths that the insect was in the larval stagee. In 1\$97, while the honse was heing painted, the painters all sufforcel more of lass. Their distress was so great that they were obliged $u$ step their work and hathe the face, hands and alms with sedat water to inct relief. Wr could not hang ont the chothes, as the latire would eling to thern, especially to the flamnels, and when wom they womld biully imitate the skin. 


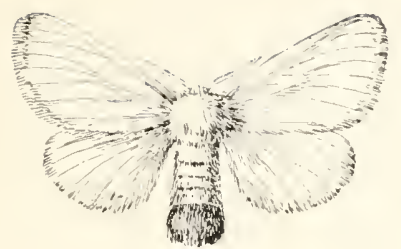

FIG. :

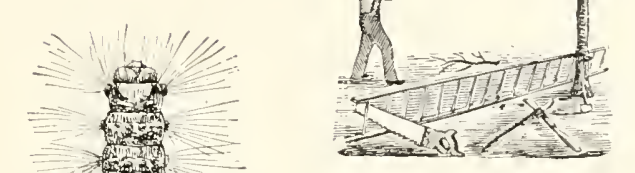

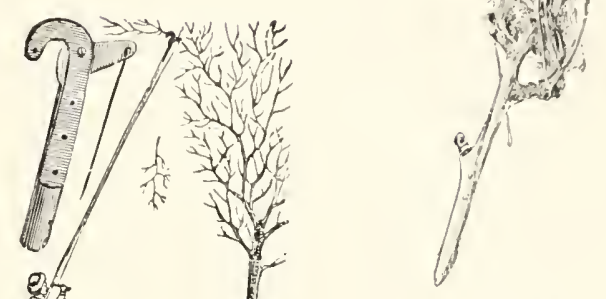

\section{FIG. 3.}

FIG. 2.

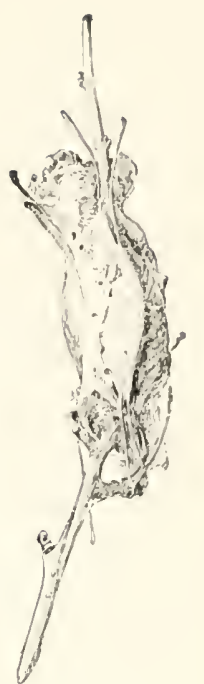

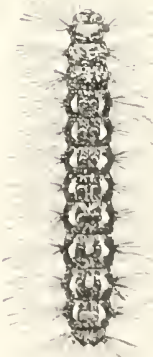

Fig. :5

FIG. 4.

\section{Explanation of Plate}

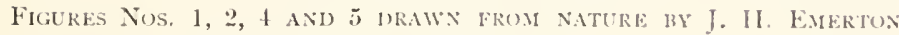
No. 1. - Female brown-tail moth.

No. 2. - Winter web of brown-tail moth caterpillars.

No 3. - Pruning shears suitable for removal of winter webs.

No. 4 - brown-tail moth caterpillars, enlarged.

No. 5. - Brown-tail moth caterpillars, natural size. 

Mrs. J. A. Chabot, 15 Park Street, Somerville, states :-

We were all badly poisoned by the eaterpillars. We conk not go into the yard without getting the irritation on the neck and arms, although we covered ourselves up as well as we could, in order to escape them. The man who took care of the yard was badly poisoned. Only a few eaterpillars got into the house, but I suppose they came in on our elothing. This spring, when putting the screens on the windows, I noticed some of the eocoons on the elapboards, and scraped them off. As a result, my neck became badly poisoned.

Nicholas Fleming, corner of Kent and Beacon strects, Somerville, says :-

The poisoning by the caterpillars was truly dreadful. Every time we went into the yard we had to protect ourselves alsont the neck and bead, to keep them off.

Mr. C. E. Kemniston, 17 Park Street, Somerville, writes :-

Both myself and family were greatly troubled by the sting or bite of these caterpillars. It seemed as if they poisoned us whenever we went near one of them. The webs male by the insects seemed to be poisonous. We had an awful time with them, and my son's face and hands were so badly puffer up, that he had to call in a doctor.

Mrs. IV. I. Chase, 85 Vine Street, Somerville, a most intelligent observer of the habits of the moth, states:-

In 1897 the caterpillars poisoned us terribly, and even now, when we go ont and swep down the sides of the honse where the cocoons are, we get poisoned in the same way. While putting a new roof on the house my lusband was nearly wild from the pain, and my neighbors tell me that every time they wash their windows they are poisoned.

Mrs. J. A. Kincaid, 88 Vine Street, somerville, says:-

Our whole family was badly poisoned by the caterpillars. It took us all summer to get rid of the poison. Even now (October, 1898), when we get overheated the poison breaks ont again on our bodies. One of my neighbors was so unfortunate as to get poisoned in one of her eyes, and had a lard time. 
Mins Went of 12 Prenton street, Somerville, on returning hume from an absence of several weeks, -

was badly poisoned by the caterpillars. I had not been home twenty-four hours before I was poisoned. I did not know that the insects had gotten on me, and at first thought I had the measles. The trouble lasted for several weeks, and then gradually wore away.

Ifenry Foster, 23 Park Strect, Somerville, says :-

The caterpillas did not poison us until they got very thick. I suffered badly with them; I could not get rid of them, and changing my elothing seemed to do no goot. Our neighbors were troubled more than we were. One of then was so ill that she had to call a physician.

J. A. Merrifield, previonsly quoted, states :-

In 1897 we were much bothered by the poisoning of the caterpillars. You coulet not sit uncler the trees ten minutes before you would begin to foel the itching sensation. You might not find a caterpillar on you anywhere, but it would be ouly a few minutes before you wonla begin to iteh.

Mrs.J. OComnell, 82 Beacon Street, Somerville, says:-

This smmuer whenever we sat under the trees we would have a terrible itching. The eaterpillars poisoned me very badly. My hands, arms and face were covered with rash, and my children were broken out in the same way.

\section{Serere Cuse of Poisoning.}

From the nature of his work, Ciranville A. Walker, 9 I aring street, somerville, became badly poisoned by the insect, his wase being one of the nust severe in the devastated district. It is of farticular interest, sinere the nettling came uot from the caterpillar, but from the cocoons spun on house walk. He has writton us:-

I wats painting a house on Vine Street in July, 1897. 'There were some caterpillars on the trees anct many webs contaning cocoons. Shone of the braluchus were so near the house we were obliged to cut then off. The louse was covered with coeoons also: we found them under the clapboarls, and of course had to 
brusl them off. My rrists and arms were poisoned, ant soon became a sight. Fome of my men were also badly affected, and all of them were more or less poisoned. It was terrible, - simply terrible! I had to gro to a loctor for relief, and he gave me an ointment to allay the irritation. A neighbor of mine whose fanily liad suffered severely from the poison of the brown-tail moth suggested the application of alcohol, as it had relieved her. This neighbor stated that each week they were freshly poisoned by the clothes, which, hanging on the line, cane in contact with the hairs of the eaterpillars; as a result, the skin was irritated when the clothes were worn.

In my own case, not only were my arms and wrists poisoned, but my whole body. The aleohol allayed the irritation so that I could get a little sleep, but the trouble lasted over a month, and was simply torture, the heat greatly intensifying the suffering. If I had known abont it, I wonld not have painted the louse for double the price of the job.

A niore serious case, no doubt complicated with other ailments, has been described to us by Mrs. Johm II. MeGarr, 80 Vine Strect, Somerville, as follows:-

I first noticed the brown-tail moth in May, 1897. My mother discovered it, and called my attention to it. She saw the little caterpillars crawling about, and beg:u killing them; but the more she killed, the more numerons they seemed to grow. Soon little white blisters began to come out upon her neck, and at last, about the 20th of May, she beeame rery sick, and we were obliged to get her away from here, because she was in such a bal state. The poison seemed to affect her entire body. After she had gone I becane quite sick, also, and conld not stay liere, but was obliged to be removed. I was quite wak from the irritation cansed by the eruption. When I serateled the irritated spots, little blister's wond form. 'The doctor who was called in to attend my mother' said they had poisoned her blood. She grew worse, and finally died of this poison alout the midule of August. "Ilue doctor sain her age was against her recovery; but she was a remarkably wellpreserved woman, and in fairly good health before this occurence. My son also was taken quite sick, and funally beeame so ill that he also had to be removed from this house. Erorything I touched in the house seemed to be poisoned by the caterpillars. When the cold weather came I began to get better, but I have never entirely recovered from the effects of the poison. We had the 
moth again in 1898, but it was not a circmmstance to what it erel hat been the previous you. No one who had not seen it would helieve what a scourge it was in 1897. When my husband came home and put on his elean flannels, he said they mate him almost crazy. The caterpillars probably got into them as they lung on the line. 'The insects were all over the house, and the trees were a terrible sight.

\section{Statements from Physirians.}

So severe was the suffering caused by these inseets that the services of physicians were in frepuent denand. Statemonts from doctors liring in the infested district and treating a great many cases of caterpillar "poisoning" are of particular interest, as giving an acculate summary of the matter from the medical stand-point. Two well-known physicians of large experience have kindly given us the statements which appear below.

George E. Orgood, M.D., 283 Highland Avenue, Somerville, writes :-

'The past summer (1898) I have hat, in round numbers, fifty cases of what is called dermatitis, or skin disease prodnced by the brow-tail moth. Wherever the hair strikes the skin it cunses either small or large blotehes. It even goes so far as to produce blebs, an affection of the skin which varies from a little red spot up to a large pustule, with pus or matter in it. 'The first attack lasts about a week, but one can be poisoned just as many times as the hair touches the skin. The after-effects seem to be trivial, muless a person has tuberenlosis or dropsy. In a dropsieal patient it is very bad, aggravating the tronble. On Summer street I had thee eases of poisoning in one fanily, and on Spring IIll Terrace I had cases in seven houses. I protecter myself from the affection by using disinfectants after being near the moth. I find that people with liglat complexions are affecter, apparently, more than those of dark complexions. By the former it seems to be absorbed by the system, and the lymphatirs are swollen. I do not know of a ease where the lymplatics have been enlared in a person with lark complexion. In 1897 there seemed to he less tronlule from poisoning than in 1898. I had hut about lif teen rases. We have had ciute a number of the moths about our place this year, although wo hal the trees thoromghly cleaned hast fall. Wo have found them (rawling up the tres, making their cocoons in them and muler the eaves of the louse. 
Dr. O. A. Gibson, 22 Summer Street, Somerville, writes :-

The first we saw of these moths was in 1897. The first eases of poisoning I saw were on Spring Hill Road and Park Street. I saw a number of cases, and they were all about the same, except that they varied in point of severity. Some of the cases were very obstinate, and did not respond well to treatment. 'The same symptoms developed in nearly all eases. The trouble began with an intense irritation; then an eruption appeared, resembling eezema, with a sort of a watery blister on the top. 'There was intense irritation all over the body, on the head, arms and limbs. I saw numbers and numbers of cases of this poisoning; I should say nearly a humlred cases in all eame under my observation. The irritation seemed to remain, and was much worse than that caused by poison oak or poison iry, and was not so easily gotten rid of. I treated most cases with some cooling application. Some cases were decidedly obstinate, but no case was serious enough to menace the life of the patient.

\section{The Chemistry of it.}

A great deal has been written in European works about the nettling properties of the brown-tail moth, and varions conjectures made as to the cause of the trouble; but the general consensus of opinion seems to be that the nettling is eaused by a poisonous substance in or on the fincly broken hairs of the latve, eoning in contact with the skin. Many also beliere the eocoon to be eren more troublesome than the larve. In an article in "The Entomologist," Vol. 17, p. 276, 1884, written from Chichester, Eng., it is stated that the moths of this species possess this stinging property, and the opinion is expressed that the irritation is caused by the white hairs that finge the inner margins of the wings.

Mr. ('. G. Barrett, in his excellent work on the "Lepidoptera of the British Islands," Vol. II., p. 294,1895 , writes as follow: :-

With the silk composing the cocoon are interwoven the lutirs of the larva, which beeomes brittle, and, when the bush or hedge is disturbed, are thrown out as a fine dust, which, sticking to the skin of the hands, face or neck of a passerby, cumses :m intense irritation, with inflammation which closely resembles nettle-rash. It is on record that a thick haw thorn hedge upon which larrat and 
cocoons have been abundant has retained for inonths the power of thus affecting any tender-skinned person rashly assaulting it with the beatiun-stick. Mr. I1. Moncreaff noticed a larva rubbing its hairs across the scarlet tubercles on its back, and upon examination fonnd at the base of each tubercle a valie, opening to a gland from which an oily substance exuded. 'This oily substance he found. on being applied to the skin, to produce at once inflammatory swellings, and all the irritation usually caused by contact with the liairs.

It is woll known both to entomologists and to the layman that certain insects carry specific poisons, which when injected beneath the skin eause acute pain. Bees, wasps, mosquitoes, bedbugs and other insects fall in this rlass; and chemical investigations have shown that the poisonous principles are usually well-defined organic compounds, capable of being recognized by chemical tests. This being the case, it was at first silpposed that the harirs of the eaterpillars contained such a principle, and that the chemist of the gypsy moth committee, Mr. F. .I. smith, M...., would soon determine its nature. A larece amount of material, such as hairs, eocoons and moltod skins, was submitted to Mr. sunith, who extracted them with various solvents with the lollowing results, which we quote from Mr. smith:s notes : -

I male a number of extracts of the hairs with each of the re-agents mentioned below, some of the extracts being of the hairs alone, others of the molted skins, and still others of the coroons which contained hairs in great numbers. 'Tle reagents userl were: water, alcohol, ether, chloroform, petrolem other, scetone, acetic ether, dilute sulphuric acial, dilute caustic potash. I tested each of the extructs after digesting for some homrs, and in each case they nettled the skin. (On the other lama, the filtered extrats (freed fom the hairs) (aused no irritation of any sort when applied even where the skin was broken. Careful ehemical tests failed to slow the presence of any oremie aciols or alkaloids. Hence I am lert to holieve that the irritation is of a mechanieal nature, cansed by the hrittle, fincly barbed hatrs, and not due to a toxic prineiple.

bofore submitting the material to Mr. Sinith, we had alremly di-covered that the irritation was not caused by 
the long barbed lairs (Plate ?, Fig. 5) nor by the white branching hairs (Plate 9, Fig. 1), but by the very minute barbed hair's which we eall the nettling hairs, occurring in very great numbers on the subdorsal and lateral tubereles of segments 5 to 12 inclusive (Plate 9, Fig. 3), and also on the tubercle at the base of the long spines (Fig. 4). These nettling hairs are very small, only about one two hundred and fifticth of an inch in length, very sharp at one end, and with two or three barbs at the other end and many along the sides. These barbs are so arranged that when these nettling hair's fall upon the skin any movement will eause them to work into the flesh.

The nettling of the skin may be caused by eontact with the eaterpillars in either of the last two molts, the cocoons, or to some extent with the moths; but contact is not necessary, as these fine nettling spines may fall or be blown by the wind. Cases are on reeord in England of travellers being affected when the wind blew strongly from infested hedges along the side of the road.

A careful examination of the caterpillar's in each molt shows that the nettling spines do not oceur except in the last two stages, or after the row of white spots appear along each side of the eaterpillar. A great quantity of these nettling spines are always present seattered through the cocoon and more or less over the surface of the pupa, but in every case they appeared to have como from the last larval skin, and never to have developed from the pupar. An examination of a large number of moths of both sexes showed many of the nettling spines seattered orer the surface of the wings and body in a very irregular manner, none of which were attached to the integument, but merely lodged among the hairs and scales of the imago. Only a few of the nettling spines were found on some specimens, while on others a large number oecumed. In a few cases many of these spines were found in a confused mass in one spot, while on another not a single ono occurred in that particular place. We must conclude, therefore, that as the eaterpillar spins its eoeoon these spines become seattered and lodge throughout the fabrie, some of them falling on to 
the surfice of the pupa after the last molt; and when the moth enereses and works its way out through the cocoon, more of these nettling spines are dislodged from it or from the molted skin and become entangled among the scales of the moth. This will explain the unequal distribution of these spines over the surfice of the moths, and the reason why some possess the nettling moperties much more than other's. There is nothing in the structure of any of the seales or hairs on any part of the body or wings of these moths that could cause them to produce any nettling sensation.

\section{Fallacies about the Insects.}

Is might be expected, nuany false notions prevail concorning the manner in which the insects cause the so-called poisoning. These fallacies are not confined to the average citizen, for even physicians, arguing from analogy, no doubt, have fallen oceasionally into crror on this point. It may be well to state, once for all, that the aterpillars do not sting, since nature has wisely denied them the apparatus for stinging, as that term is commonly understood; that they do not hite, for they have no beak such as is possessed ly the mosquito or bedbug, while, from the anatomy of their timy, hlunt jaws, it would be impossible for them to eut through the human skin: that they do not eject a baleful remen, fin they have neither the venom nor the means for ajecting it. Lacking all these attributes dear to the populitr fancy, these inseets, with their brittle, barbed hairs applied in alleretionate contanet to the human cpidemis, still funsise a means for making one truly long for a place "Where moth and rust doth not corruyt."

\section{Rermerlies.}

The injury to the skin being a mechanieal one, remedies mu-t be sengeht amonge these matcrials which soften the skin amet aid in the expulsion of the hatis. Of these, vatseline atnd strent oil are anong the bert. Aleohol has been used

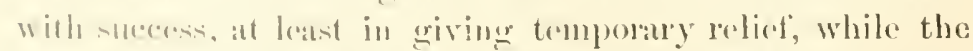
sane is true of the numerous coal-tall disinfectants now on thr. matront. So prevalent is the dermatitis from the cater- 

I'late $\%$

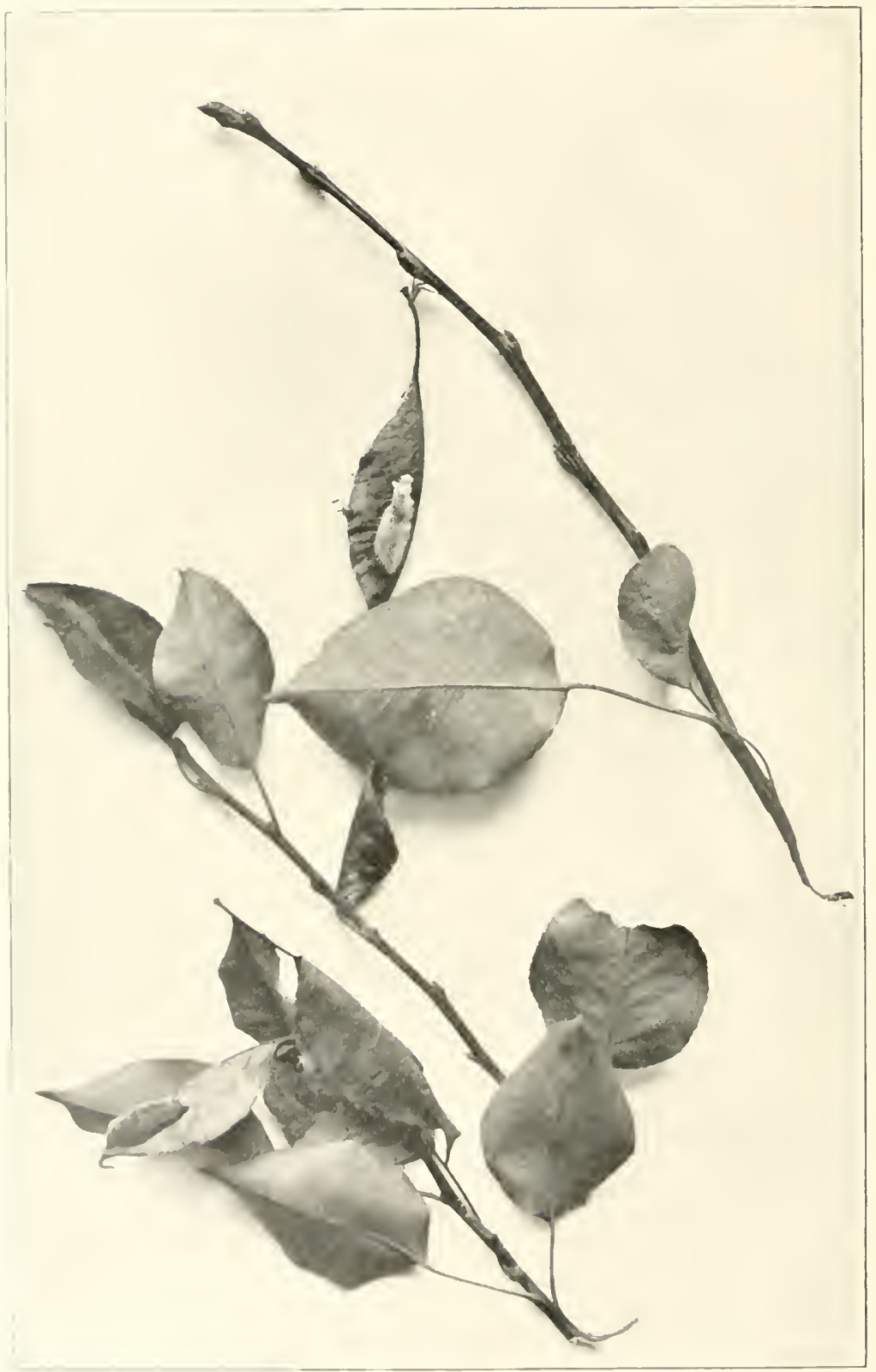

Typlcal bulr-covered oge masses of brown-tall moth; laid in July, 1899. on ereas sprayen May 18, 1899, with arsenate of lead. So well did polson adhere that caterplllars died as fast as hatched.

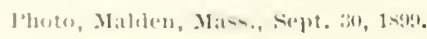


pillars in the metropolitan distriet in the summer months that druggists put out special lotions for the "brown-tail moth itch," many of which are meritorious.

\section{Life Histoliy.}

The moths emerge from the cocoons from the 1 st to the 20th of July, and fly principally by night. In marked contrast to the gypsy moth, the female brown-tail moth fies freely, and when caught up by the wind is often transported long distances. Mating takes place soon after the wings are developed, and egg laying begins a few hours later. The eggs are usually deposited on the under side of leares on the outside of the trees, preferably near the top. The egg mass is much like that of the gypsy moth, although smaller and more elongated. It contains from two hundred to four hundred small globular eggs, thickly covered by a mass of brown hair from the tip of the abdomen of the moth. A typical egg mass (Plate 7 ) is about two-thirds of an inch long and about one-fourth of an inch wide. If the moths are disturbed while laying, or reach the edge of the leaf on which the eggs are being deposited, they often change the direction in which they move, or go to another place and recommence the work. Whenever such changes oecur, the resulting egg mass is more or less irregular in form. Oecasionally the eggs are deposited on branches and trunks of trees, on fences, on the walls of houses and even on lamp posts.

\section{The E!y!!.}

The egg is honey-yellow in color, of a nore or less globular form, being about one-thirtieth of an inch in dimeter, and hatehes in from tifteen to twenty days. The young larva feed at first on the leafl to which the corg mass wats attached, but soon migrate to other near-by leares, alwatys returning at night to their original feeding place.

\section{The Winter Web (Plates 2, 13).}

The hibernaculum or winter wob of this insect is of such a novel nature, at least to Ameriean entomologists, that a detailed deseription of it may well be given at this point. 
In the fall the young larve feed upon the epidermis of the leaves only, camsing them to turn as brown ats though acorched by fire, and while still young commence the dwelling in which they hibernate during the winter (Plate 8). These winter webs of the brown-tail moth, constructed at the ends of the twigs, are from one to four inches in length and firom one to one and onc-half inches thick, depending upon the kind of tree on which they oceur (Plate 6, Fig. 2). 'The insect readily adapts its style of arehitecture to the material at hand. making compact webs on pear and willow, and large open webs on maple and ash. Each web is composed of a tenacious silken hibernaculum, enclosing leaves from which the epidermis has been consumed. although the outer leaves on the web may not lave been attacked. The webs: are firmly attached to the twigs by stout bands of silk. Almost inviblibbly the weh commences where the egg cluster was deposited, and remains of it can usually be found on or in each web. Exit holes sometimes remain open on the webs throughont the winter, but as a rule they are closed by the matting together of the web under the inthenee of rain. The webs consist internally of mumerous latyers of silk, rnclosing a great many small, irregular, silk-lined chambers, which are often commerted, and contain from six to filty lavere. The nsual number found in the ehambers is about a doren earh. The larvae are also often found in the galleries in the web. The lowest part of the web is usually full of fine blarek excrement, and the cast-ofl' skins of the first molt weere in many of the elsmulurs. Twenty winter webs of the brown-tail moth were opened fan. 2.1, 18.99, and thrir immates carrefully eomnted, the wobs being dissected Inder at lens, so that none of the inseets might be orerleckerl. The wobs contained respectively 25:3, 15!4, 253,

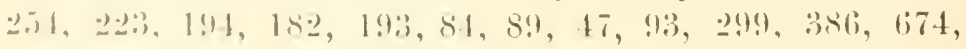

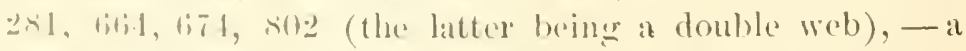

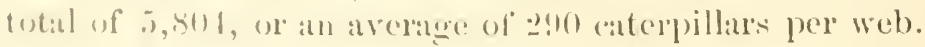

\section{'The Lerru.}

The new lateloed lantal is about one-twelfth of an inch lomg, with a shining black head, over the surface of which arn a fow palw bownish-yellow barbed hairs. These hairs 
l'iate. - .

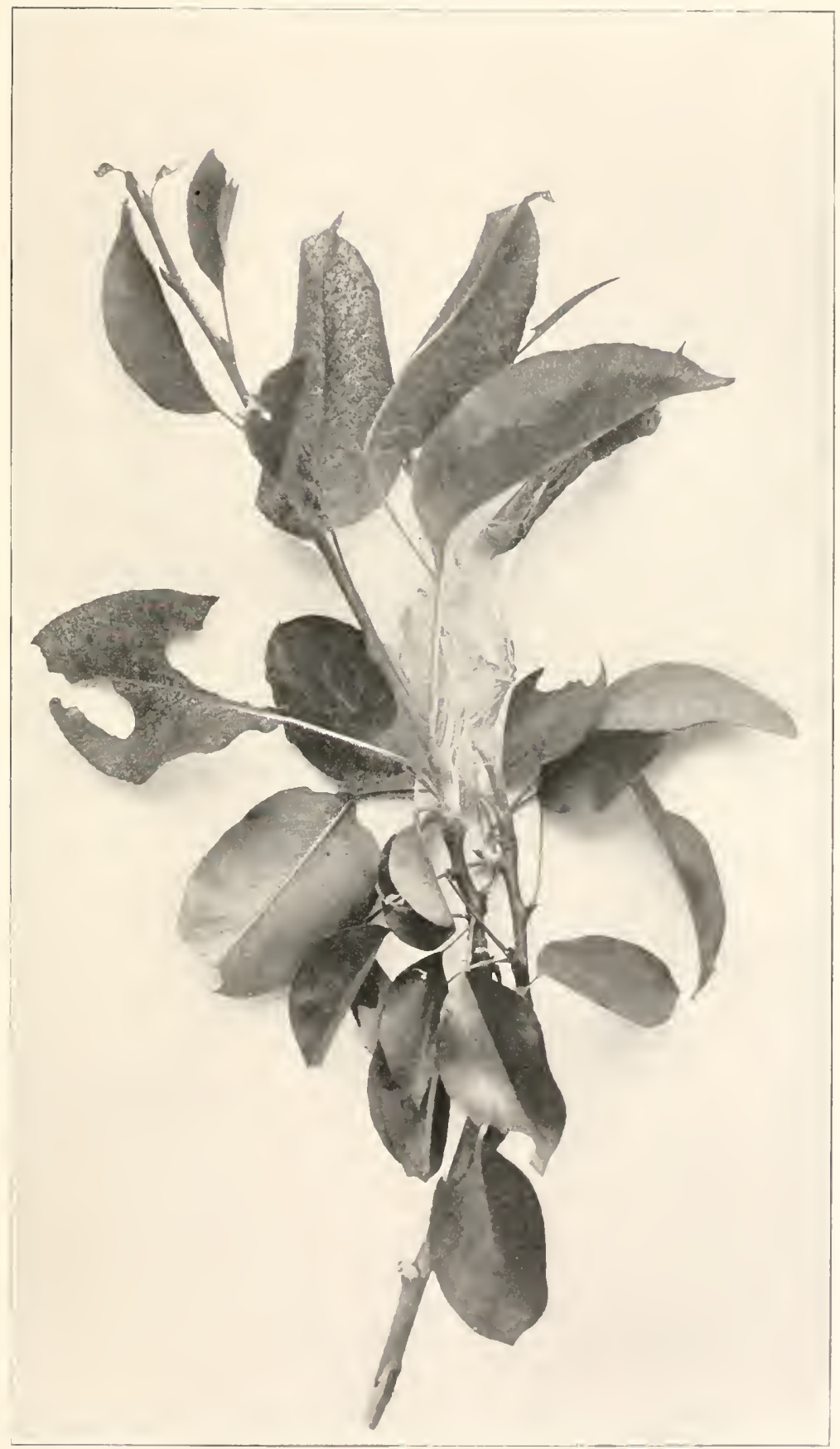

Caterpillars of the brown-tall moth commencing to spin their winter web on a pear twig. 

vary in length, but none of them are longer than the width of the head. The body is dull yellow, but this is obscured by the color of the tubercles, which are nutuch darker than the gronnd color of the body, some of them being black. The tubereles are arranged as in the mature larva, and are armed with harbed spines like those on the head, except the subdorsal row, which has smooth, shin'p-pointed spines, dark at the tip, lighter at the base, and about as long as half the diameter of the body. The length of this stage is from four to six days.

The larva after the first molt is about one-fifth of an inch long, with a shining black head, clothed with seattering pale brownish-yellow hairs, as in the preceding stage. The ground color of the body is dull yellowish, and the dark color of the tubercles is so pronounced as to give a darker appearance than in the preceding stage. The snooth, sharppointed spines of the subdorsal row of tubereles are no longer present, but are replaced by the ordinary barbed spines: and the subdorsal tubercles of the 5th and bth segments are covered with a short, dense tuft of chestnut-colored feathery hair.

The larva after the second molt changes but little before hibernation, except in size. 'The head is blark, and clothed with barbed brownish-yellow hairs. The body is dark brown, with two parallel longitudinal redish-yellow lines between the subdorsal tubereles, extending from the head to the 10th segment, broken between the segments and also on the 5th and bth segments by the tufts of hair, which are similar to those in the preceding stage. The coral-red retractile tubereles on the top of the 10th and 11th segrments appear after the first molt, and are present in all the remaining larral stages, though at first they are of a lightyellow color.

The larva stop feeding and go into hibernation in their winter webs (Plate 14) early in September, some having molted onee, others twice and a few three times.

\section{Emergence in the spring.}

The larve generally emerge from the hibernating tents from the 1 sth of Nareh to the 20th of Ipril, though the time varies somewhat, aceording to whether the season is 
arly or late. The earliest record of emereence was by Mr. 1. F. Burgest, who observed the young aterpillar's cuncreing on March 18,1898 . By the last of 1 pril the larve are uthilly well at work, feeding on the unfolding buds of the featr and apple: white those on the elm and oak do not fare as well, since those buds open later in the season. The larve slow but little method in feeding on the buds, simply burrowing into and often entirely consuning them.

$\therefore$ for as has been ohserved, there are three molts aller ancerence from the winter cuarters bofore pupation. In the quiet state, just before the first molt in the spring, the latris is about one-fonth of an inch long, and difler's only in size and in having the ground color of the body a little darker than it was before hibernation. They retreat into the winter web, where they rentin quiet for twenty-four hours or more before nolting.

The first molt in the spring oceurs in about eight days after the larva energes from the winter web, when it dillers from the preeceding stage in size, which is now about twofiftls: of an inch in length: in the ground color of the body now being a dark, smoky brown; and in having much longer spines, the longest of which are abont three times the diameter of the body.

The second spring molt occurs about the middle of May, when the liurvat is about three-fifths of an inch longe. This statge is similan to the preceding, execpt that the ground color and makinges ane more like those of the full-grown larrat, though not nearly so bright.

The third spunge molt ocenrs during the latter part of May, when the eatcrpillar is from three-fourths of an inch to an inch in length, and takes on the matrings and charaeteristies of the mature larval. It now has for the first time the white branched hairs on the upper side of the lateral tubereler, on segments is to 12 inclusive, and the nettling lair (Plate9, Fig.: : on the subdorsal and lateral tubereles of these sallle sogencints.

The forrth and lant sprillg molt occurs in the early part of June, when the larva is from an inch to an inch and a equarter in length. The head is palle brown, mottled with 
darker brown, and has light-brown hairs scattered over the surface. These hairs are finely barbed, and similar in structure to the long ones arising from the tubereles of the body (Plate 9, Fig. 4). They are much shorter, however, the longest being half the width of the head. The basal segment of the antenne and palpi is sordid white.

The body is dark brown or black, with numerous markings of a dull yellowish color, sometimes inclining to a dull reddish. These markings are as follows: the thoracic and anal shields, the katter often more or less dark brown in the middle; two parallel, irregular and more or less broken lines along the middle of the back, represented on the anterior segment by two rows of spots of variable size; a small space around each of the tubercles: many short, irregular, transverse streaks, most numerous on the sides and beneath. A cluster of reddish-yellow, finely barbed hairs of unequal length arises from each tubercle, while the subdorsal and lateral tubereles on segments 5 to 12 inclusire are thickly corered with fine barbed hairs (Plate ?, Fig. 3), which give these tubercles a dark-brown color and the appearance of velvet, under a lens. These are the "nettling hairs." There is a fleshy, retractile, coral-red tubercle on the middle of the back of segment 11 , and a similar one in the same place on segment 12 . In one example these tubercles were abnormal in size and position. one being larger than usual, a little to the left of the dorsal line, and between segments 10 and 11 ; while the other was less than half as large as the first, and on the right side of the dorial line, more than twice as far from it and slightly farther forward than the other.

The legs are dull reddish-yellow, with the claws and the outside of the basal segment black. The spiracles are vertically oval, and shining black. The surface of the body under a onc-half inch objective has a shagreened appearance, with numerous fine, short hairs scattered over the surface.

The thoracic shield on the top of the $2 \mathrm{~d}$ segment (first after the head) is wider in front than behind, and is divided by a transverse impressed line into two parts. Host of the 
hairs along the front edge incline forward over the head. They valy in length, the longest being about equal to the width of the head. 'Those on the posterior part of this shield are short, and sparsely seattered over the surface. A small tuberche ocens behind the outer and of the thoracie shield, and in line with the posterior pant: the next is larger, oblique in front of the spiracte, and elothed with long hairs which incline forward more or less; the next tuberele is about half way between the last and the leg. The ad and Ith segments lave three tubereles on each side in an oblipue low above the spiracular line, and two below. These two are represented on each of the sorments of the body after the head, forming two subspiracular rows of tubereles. Above the spiracular line, on each side of segments 5 to 13 inclusive, are two laree, round, nearly equal-sized tubereles, which may be called the subdorsal and lateral tubereles. The harirs on the head and other parts of the body are similar to those represented in Plate 9, Fig. 2, and the long ones in Figr. 5, exeept those of a clcar white color (Plate !). Fig. $1)$ on the uner side of the lateral and a few on the outside of the subdorsil tubereles, on segments 5 to 12 inclusive. These hairs form a row of eight lunate white spots along each side, which is the most striking chancteristic marking of the caterpil lar.

The larve spin their eocoons and pupate during the last half of Jume, remaining in this stage about twenty days. A farorite place for pupation is the leaves at the tips of the hranches, and not unferquently a dozen or more larve atrimble and spin a rommon wob, within which each eaterpillar fome its own cocoon and transforns into the pupa. Inother favorite place is under fonces and beneath the edge of clapboarcls. In $18 ! 97 \mathrm{Mr}$. Kirkland saw a matss of cocoums nearly two fect across in the eornice of a house on Vine strest, somereville.

The coroons atre compesed of grayish silk, so loosely construeted that the pupa maty be readily seon through it. The puptis about five-righths of an inch long, of a darkbrown molor, with un arenical spine at the and of the aldomen, this spine buing amed with a eluster of minute hooks 
at the extremity. There are smooth, yellowish-brown hairs scattered over the abdomen and top of the thorax, but none on the antenne, leg or wing covers.

\section{The Woths.}

As already noted, the moths emerefe from the pupal stage from the 1st to the 20th of .uly, the time varying, areording as the season is early or late. In 1898 the height of the flying season was July 16 , in 1899 it was July $s$, while in 1902 it was July 14 . They are esientially night-Hyers, only a few being seen on the wing in the day time, while the others remain at rest on the trees, fences and uncler side of leaves. In an hour or two after sumset a few of the moths venture forth, the number increasing as it grows dark, and from 10 o'clock till midnight the moths fly in the greatest numbers.

The average expanse of the wings of the males is one and three-tenths inches, and of the fimales an inch and at half. Head, thorax and wings snow white: antenna white above, with the under side and pectinations yellow; abdomen, above, smoky brown, more intense posteriorly. On the end of the abdomen of the female is a large globular tuft of hairs, which in different lights shade from golden yellow to dark brown. In some females the hairs of the under side of the head, thorax and abdomen are tinged more or less with pale yellow. This is more pronounced in the males, where, on the under side of the head, pectus and costa of the fore wings, it is dark brown.

In July, 1897, a quantity of cocoons and puper wats gratlered and placed in a lare glass-covered box, the moths being removed as they emerged. The following table shows the relative proportion of the sexes :- 


\begin{tabular}{|c|c|c|c|c|c|c|c|c|c|}
\hline \multicolumn{8}{|c|}{ DATE. } & \multirow{2}{*}{$\begin{array}{c}\text { Maleg. } \\
\end{array}$} & \multirow{2}{*}{$\begin{array}{r}\text { Females. } \\
2\end{array}$} \\
\hline July 7 , . & . & . & & . & . & . & . & & \\
\hline$\&,$. & . & & - & . & . & . & . & 12 & 8 \\
\hline 9, & . & - & . & - & - & . & . & 41 & 38 \\
\hline 10, & . & & . & · & . & . & . & 1.13 & 135 \\
\hline 11, & . & . & · & - & . & . & . & 32 & 46 \\
\hline 12, & . & . & . & . & . & - & & 61 & 54 \\
\hline $1: 3$, & . & - & . & · & . & . & & 61 & 100 \\
\hline $14,$. & & & . & . & . & - & & 21 & 53 \\
\hline 15 & . & - & . & . & . & · & & 9 & 12 \\
\hline 16 & & & • & . & . & . & & - & - \\
\hline 17. & . & & . & . & . & & . & 1 & 3 \\
\hline 'lotals, & & . & . & & . & . & . & $; 999$ & 451 \\
\hline
\end{tabular}

Siesen female moths which had not deposited their egas were killed and arefully disserted. They were found to rontain (newes atollows: $344,300,217,286,257,145$, $20 ! 9$, a total of 1,75.5, ar an arerage of 2.51.1 per moth.

\section{MINTIHTHON.}

The principal distribution of the brown-tail moth takes place at the time when the femate moths are on the wing.

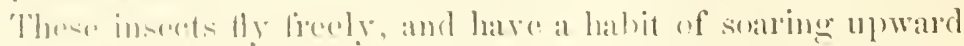
above the tren tops and huildings. When the moths in their nocturnal dlights have thus risan in the arir, they are often drifted by the wind oxere long distanese. In exeetlent illustration of the distribution of tyine mothes by air currents

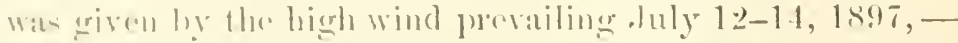
a time when the llyiner seatson of the hewn-tal moth wats at its hoight in fomerville and ('ambridere. I few weeks previous the aterpitlar: hat swimmed in multitudes in these cities, and in due lime the white-winged moths emeraed in myriads. So plentiful wore they at this time that are lights 
Plate 9.

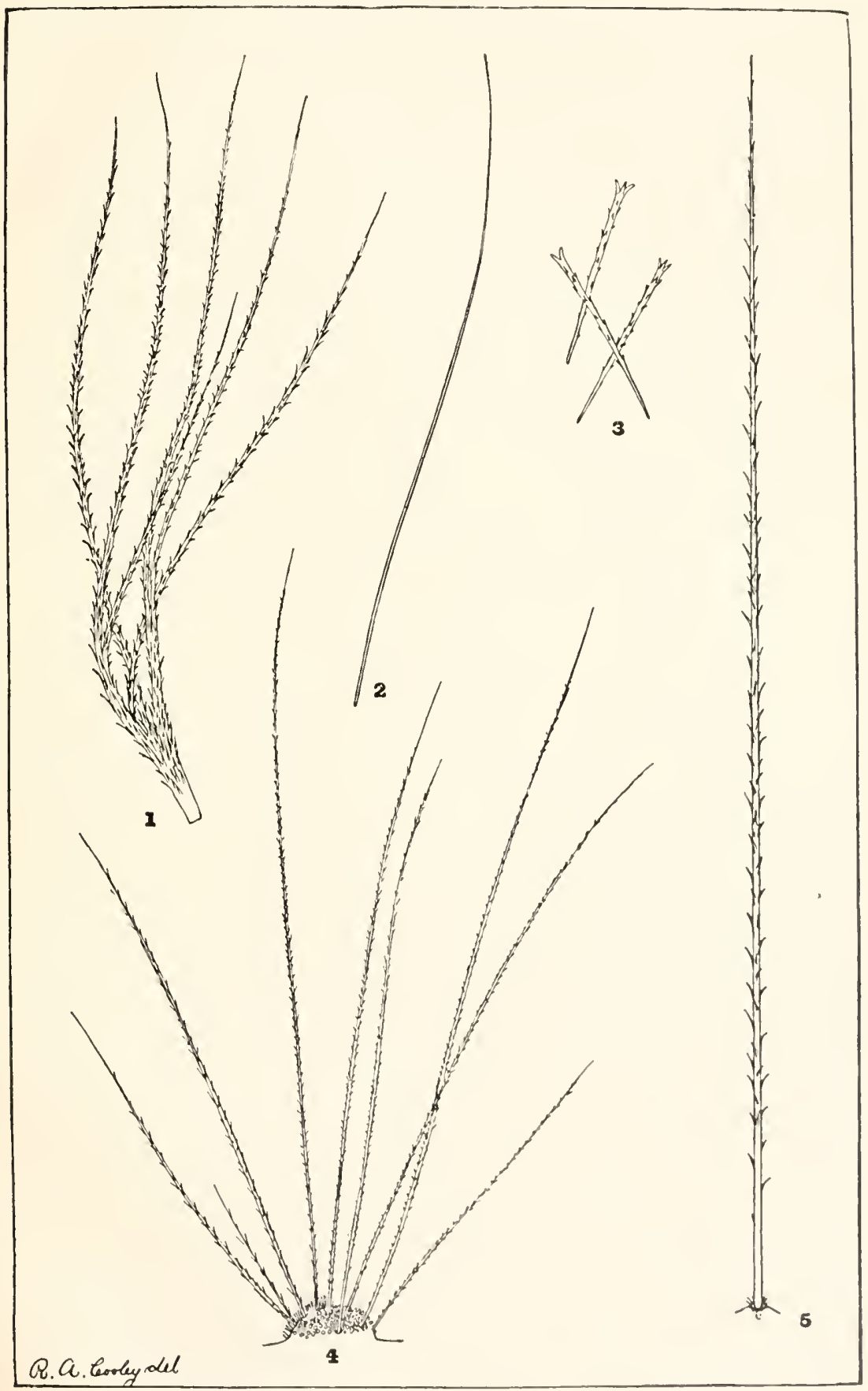

Various forms of hairs from brown-tall moth caterpillars. 

around which the insects hovered seemed indeed to be the centres of miniature snow-storms. While the moths were swaming on the night of the 12th, the wind came fiesh and strong out of the soutl to south-west, blowing steadily at the rate of twelve to sixteen miles per homr. After midnight it increased in velocity to twenty miles an hour at 2 A.x. (July 13), twenty-five miles an hour at 8 A.M., twentyeight to thirty miles an hour at noon, thirty-five miles at 5 r.M., and reached the maximum veloeity of forty miles an hour late in the afternoon. By miduight the gale had decreased to fourteen miles an hour, but increased acain rapidly, reaching a velocity of twenty miles an hour at 2 A.M., July 14 , and forty-eight miles an hour at s.40 A.x., then decreased to thirty miles at noon and twenty miles at $6 \mathrm{r}$.u. The day movement of the wind is not important, as the moths are nocturmal, but it was soom aplarent that the wind of the nights of July 12 and 13 had transported the flying insects into many cities and towns lying to the northward, while to the south the distribution was limited. Some two or three year's were neecsiry hefore the increase of the moth in the new localities was suflicient to call attention to its presence ; but by the fall of 18.99 it had been found scattered from Somerville northward to the State line at Methuen and eastward to Seabrook, N. H., - a point some forty miles distant fiom the original eolony. In the spring of 1902 the nests of the moth could be seen asily from the ear windows in every town along the eastern division of the Boston e Mame Railroad firom Boston to Portsmontl, x. II. The oecurrence of the moth at Kittery, Me., was reported in 1899 by the late Prof. F. L. Hatrey, Orono, Me. The Kittery oecurrence was donbtless due to the transportation of houschold goods from a badly infested Somerville estate at a time when the inseet was in the cocoon stage. Recently, Prof. James Fleteher, the distinguished Canadian entomologist, has reported the oceurence of the mature moth at St. Joln, N. 13. In the absence of evidence to the contrany, he believes that the inseet was transported on the steamers plying between Boston and st. John. This view is a logical one, for the trees on the islands 
in Boston harbor and along the north shore are generally infested by the brown-tail moth. It is entirely probable that moths attracted by the bright lights fly to and alight on pasing ressiels, and in this way the insects already may have been earried aceidently to many seaports. The dantrer of spreading the moth by shipping is of course greatest on the coastwise steamer's, where the boats make landings before the moths have laid their eggs and died.

When the moths are flying, they are strongly attracted to light. In tracing the distribution of the moth in the winter of $1898-99$ it was found that the most promising places to search for the insect were in the centres of population, where electric and other lights were massed in greatest number's. It is not diflienlt to understand how the swarming insects driven by the wind from the place of emergence fly onward to the nearest mass of light. This tends to bring about the infestation of the central portions of eities and towns before the pest finds its way to the outlying residential or furming districts.

Igan, the Hying moths enter brightly lighted electric and strect cars. At the flying season wam weather is the rule, and open car windows give the insect easy entrance. Mr. Kirklitnd has repeatedly seen the female moths in rapidly moving electric cars and on two oceasions in local railroad trains.

Aside from the principal means of distribution mentioned, it is mecessary to comsider the droppling of eaterpillars on toame, and the dangere from nuraery stork grown in the infirsed distriet and shipled to eustomers living at a distanee. In common with other eatepillars, the brown-tail moth lurva have a habit of spinning down on silken threads from their fierding platere, and hanging for some tinc suspended in the air. Where they are feeding on strest trees, they are frecpucutly intereepted by passing teams and are thus carried from phace to place. In the very thorough studies of the distribution of the gypey moth made by Mr. E. H. Forbush some yeals ater, it was shown that one of the chief aids in sperading the moth was the rengular continued traflic of milkmen, greecers and other's. The spinning habits of the brown- 

Plate 10.

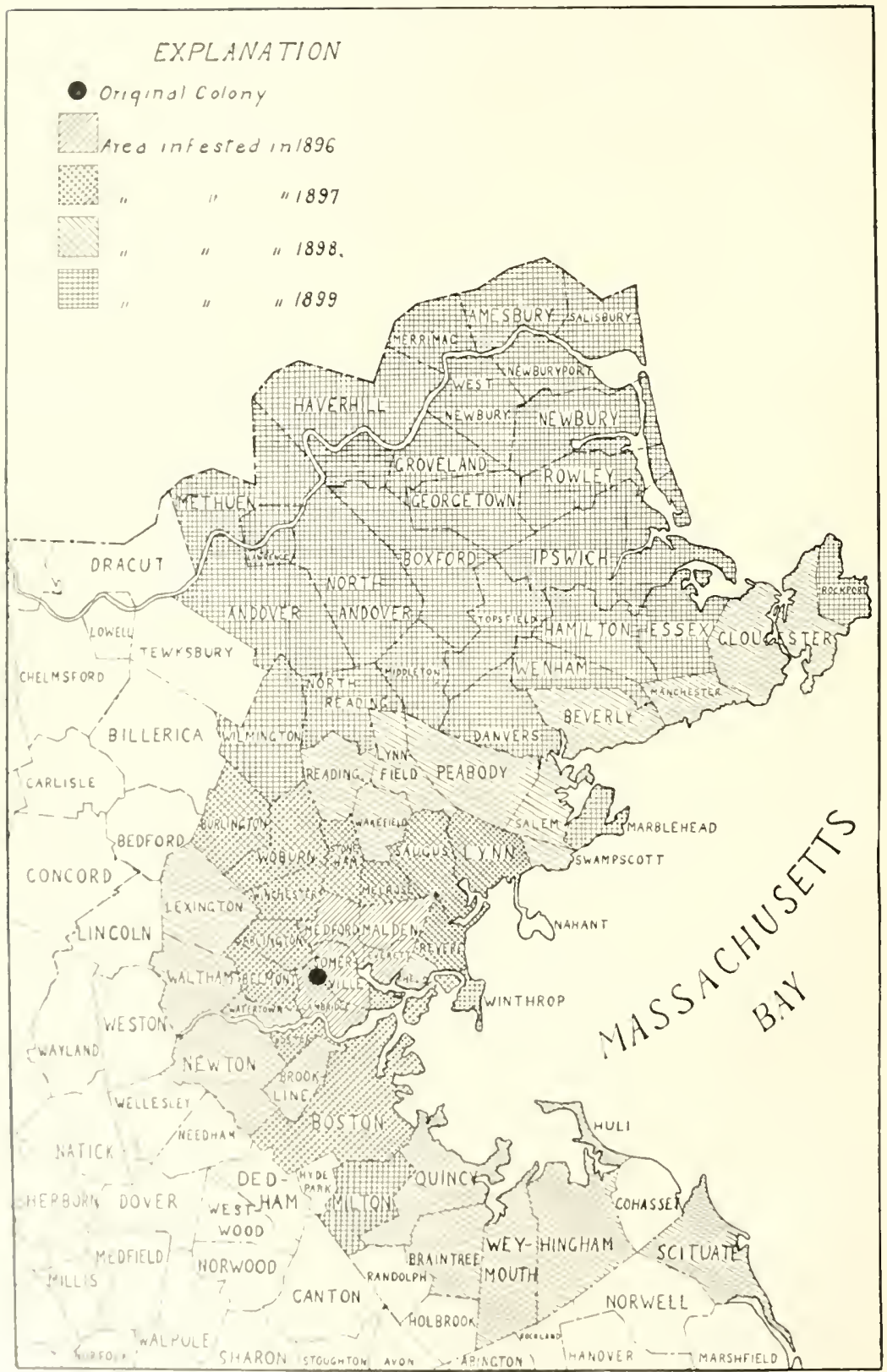

Map showing the repldy increasing spread of the brown-tail moth. 
tail moth do not differ materially from those of the gypsy moth, and its distribution by teams is doubtless of frequent occurrence.

Several eastern Massachusetts nurseries are more or less infested by the brown-tail moth, and there is constant danger that a small caterpillar web may be sent out with trees to some distant locality, and there estahlish a moth colony. This matter is one that has reeeived special attention from the efficient State Inspector of Nurseries, Dr. H. T. Fernald; while the proprictors of infested nurseries are taking overy precaution to insure the destruction of moths on their grounds and prevent its spread elsewhere.

At the present writing the moth is known to oceur in Massachusetts at Scituate on the south, westward to Brockton, Hudson and Stow, northward to Methuen and eastward to the sea. The occurrenees at Kittery, Me., and St. John, N. B., have been mentioned. South-eastern New Hampshire is also generally infested, and we fear in the course of a few decades the pest will have found its way over the greater part of New England. The neglect of a moth colony on an infested estate results in the spreading of the pest to adjoining places; neglect on the part of generally infested towns leads to the swarming of the moth and its dispersal into neighboring munieipalities. The case with which the moth beeomes distributed gives an additional reason for thoroughness in stamping out incipient colonies.

The tabulation below gives a good idea of the rapidly increasing spread of the insect. Since 1899 no aceurate records of the distribution of the moth have been kept. The area infested in 1896, the year previous to the discovery of the moth, was retermined by the finding in the spring of 1897 of the winter webs of the previous year.

Area infested, fall of 1896 , .

Siłnare Miles.

Area infested, fall of $189 \%$,

Area infested, fall of 1898 , .

158

4.8

Area infested, fall of 1899.

928

Area infested, fill of 1902 , estimated,

1,500 


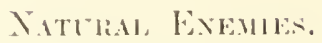

(Onc roason why the brown-tail moth is so very injurious in Massachusetts is found in the lack of the parasitic conemics which hold the insect more or less in eheck in its original home. As yet om native parasites have not adayted themsolves to this new caterpillar, and, freed from the checkis that rontrol it at home, it here canses a greater and longer-eontinued danage than is eommon in Europer. (of the Iymenopterous parasites common to aterpillars of this

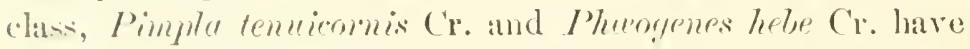
been bred in some numbers finem the cocoons. The ereatest natural aid in destroying the brown-tail moth seems to be the tiny parasite Diglochis ommiona Walk. Large numbers breed in a single pupa, and. concreging early in the season, attack othor larvie and pupae, and tisus prevent their derolopment intomoths. From a single pupa 1 is Diglochis were obtained in July, 1s!18, while from a mass of about four yuarts of coecoons over thee thousand of these paratsites emerered during the sume month. Of the dipterous parasites, the only one detrumined is Enphorocesed clarijemnis Mace. So far as we have observed, the eaterpillar is only slightly attacked by parasites of this rlass.

"The number of prediaceous bugs which asiocomble on trees infostred with the brown-tail moth carly in the spring is puite romatiable. These buges, hiberuating in sholterod localities, ragerely sock food in the first wam days of

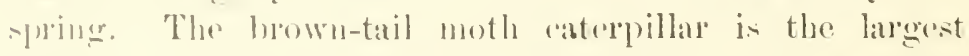
iusoret of it kimb which is at all abundant canly in the

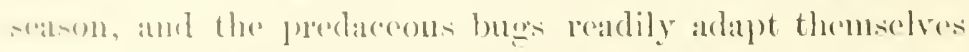
to it. 'The reanlt is erreatly to the advantage of the bugss and to the falmer. May 1, ls!)!, with the themenneter in the shadr at !o b. six tores infested with the hrown-tail moth wree "ximbined, with the result that the following

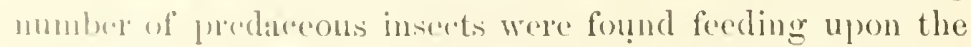
mall catcrpillats: 11:; Poulisus serierentris, 3ti l'odisus

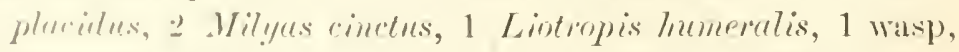
l'elistes prllipes: in other words, on the six infested trees there were 1.5z predacrous bugs at work destroying the 
larva, or an average of 2.5.2 bugs to a tree. Many of the bugs were mating, and it was not unusual to see two bugs both feeding on a single larva. The wasp made a business of tearing into the webs, extracting the lan've, rolling them up into a hall by means of the fore-feet and jaws, and carrying them oft'.

In the spring of $1899 \mathrm{Mr}$. Kirkland placed three webs of the brown-tail moth on as many wild cherry trees in rear of his house at Malden, with a riew to studying the habits of the caterpillars, the locality boing already somewhat infested. As soon as the larva emerged and commenced to feed, predaceous bugs of the genus Poulisus appeared, and in less than a fortnight had completely wiped out each caterpillar colony.

The humble toad nunt also be reckoned in the list of the enemies of the brown-tail moth. During the early summer, when the eaterpillars are swaming, large number's are eaten by toads. Seven toads taken on infested estates May $24-26,1897$, contained respectively $7,5,0,3,8,3$ and 12 brown-tail moth larve. The work of toads is more noticeable, however, during the flying season, when they assemble under are lamps, and derour the fluttering moths as they fall stumed or injured from the lamps above. Four toads taken under are lamps at somerville on the night of July 16, 1897, contained respectively : 11 male moths, i female moths; 6 male moths, 4 female moths: 7 male moths. 4 female moths: 9 male moths, 8 fenale moths.

Bats also are worthy of mention amomg the natural enemies of the moth. Where the moths swam thickest alround the lanips, the bats are eonstantly in evidence, their noiseless work being asy to trace by the falling of white moth wings. It Malden, on the night of .July 1.t, 1 s.ts. sereral bats were noticed destroying the moths around an are light. The following morning ov er wo hundred wings of the browntail moth were eounted on the ground bemeath that particular lamp. Allowing four winge to ateh moth, this would indieate the destruction of fifty imagoes by the bats at this one point.

It occasionally happens that the yomng hibernating eater- 
pillar's are destroyed early in the fall by a fingus or mold which derelops in the webs. The eaterpillar destruction from this eans is most noticeable during a fall that is especially damp and rany: we have nerer notieed it taking place in al dry fiall. It is most common in those wehs which are spun on trees with larede leaves, such as the maple or horse-chestnut. These webs are of necessity more opren than those spun on trees with smaller leaves, such as the pear or willow. 'The rain penctrates these harger and more open wels, and dampens the masses of excrement which are found in many of the chambers of the web. It is evident that when these webs become thoroughly dampened inside, the molding and death of the eaterpillats usually oceur.

\section{Electric Lighls.}

Although clectric lamps ean hardly be classed among the " natural" enemies of the moth, they exereise none the less a very important influence in destroying the swarming moths during the flying season. We lave pointed out in another flace how these lamps, by attracting the moths, materiatly increase their rlistribution. It is well to show, therefore, the good done by the lamps in destroying the swarming inserts. The moths come out in large numbers soon after the lights are turned on, and from ten o'cloek to midnight the swaming is at its height. 'The moths encirele the lamps at times in surb numbers as to somewhat obseure the light. The bodies of those killed by the electrie current drop eontimually, and by morning the ground under the lamps in the worst-infented regrons is liberally sprinkled with bodies of dead moths. C'ount of alead mothe muder five atre lamps were made at four efolock in the morning on July 16,1897 , with the following results: lamp No. 1, 236 males, 71 formales; lamp No. 2, 2!) males, 11 females: lamp No. :3, 7 males, 1 fomales; lamp No. 4,3 maless 4 females ; lamp No. 5, 22: males, 2 females.

Lamp "leancres report that they often find a quart or more of thatd nothe in the limps carly in the morning. Mr. Kirkland spent acreral nights in $1897-98$ watching the swarming of the moths, and found that towards morning many of the 
Plate 11.

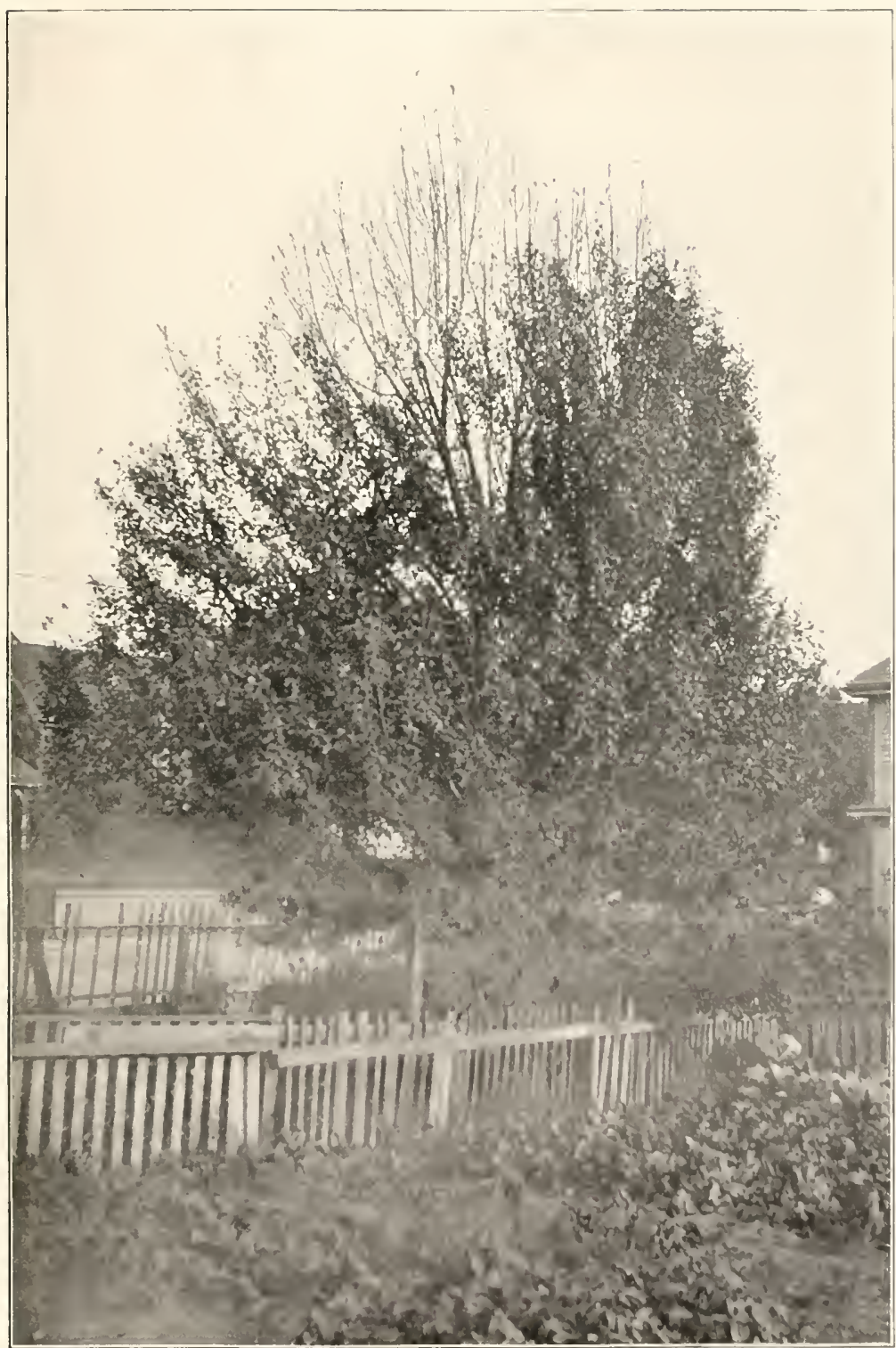

Damage by tiny caterpillars of brown-tail moth in fall. Ihoto, Medford, Mass., sept, 1, 1s:4t. 

are lamp globes would become more or less elogged by the bodies of the insects. Is soon as daylight breaks, howerer, the English sparrows swarm to the lamps and feed upon the moth bodies. They also carry them to their young. A remarkably short time suffices for these birds to remove a quart or more of the moths from the lamp globes. While the old birds evidently enjoy the moths as a morning meal, they also carry them in large numbers to their young.

\section{Birds as Destroyers of the Brown-tail Moth.}

Birds play an important role in checking the spread of the brown-tail moth. While their attacks are perhaps more conspicuous while the insect is in the moth stage, it is probable that the greatest number of insects are destroyed in the larval form, at which time many species of birds not only consume the caterpillar's, but carry them to their young. Armed as these larva are with an abundant growth of nettling hairs, it would seem that they would prove distasteful morsels for the birds, and be largely protected from their attacks. This, howerer, is not the ase; the same species of birds that feed on other hairy caterpillars, such as the tussock moth, forest tent caterpillar or gypsy moth, readily adapt themselves to the brown-tail moth eaterpillars. Of the birds feeding on the eaterpillars, the yellow-billed and black-billed cuckons and Baltimore oriole are worthy of special mention. They are common visitants to infested trees, feeding freely on the insects, and carrying them to their young. They arrive in their summer migration when the caterpillars are about two-thirds grown, and make repeated visits to the infested trees, feeding particularly on the nlisses of insects elustered for molting. As is well known, the cuckoos are formidable enenies of hairy eaterpillars. Their services in destroying the common tent caterpillar of the orehard are of highest value, and alone should entitle then to the good-will of the farmer or property owner; and this statement is also true of the Baltimore oriole. Of the other birds which feed on the larva, the yellow-throated vireo and blue jay are worthy of special mention. 
It is. howerel, when the moths ane emerging that the layman notiess more particularly the work of birds in "hecking the increase of this insect. The white moths leave their cocoons and remain in situations more or less exposed until their wing have developed. As a result of the habit of the caterpillar's in spiming their coroons in a common mass, there will often be a laree number of mothe within a small area on a fence, howse wall or other sheltered locality. The birds soon locate these fitrored spots, and often eonsume the moths even before their wings have expanded. In this work of moth destruetion the kinghird and some of the flyeatchers figme to a limited extent, but the most formidable enemy of the mature moths is the notorious English sparrow. 'That this hird, whose evil habits in driving out mative insertivorous birds are so well known, should show this distinctly boueficial trat, maly be a matter of surprise to miny students of nature: but the fact remains that the linglinh sparow, with its numerous progeny, exerts a great and henedicial influenes in checking the moth in our thickly settled distriets, - places where natural checks are often most deficient.

fuly 16, 1s!7. the time when the nothe were notably thick at Fomerville and ('anbridge, Mr. Kirkland observed whole flocks of Eugtish spatrows following along the line

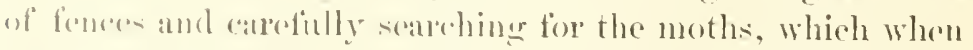
fomel were geredily devomed. The sides of the piekets and wen the bottem of the rails were cerrefully examined hy these thaplerged moth hunter's, and all moths of either sex fintud were remimmed.

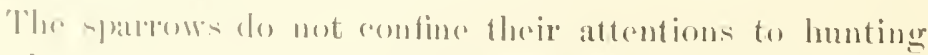

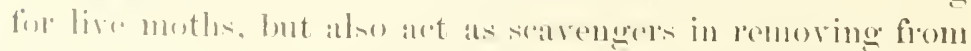

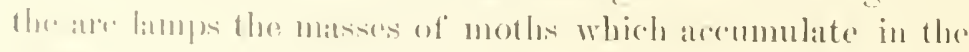

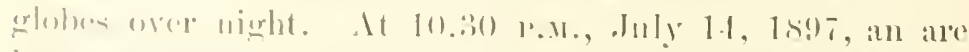

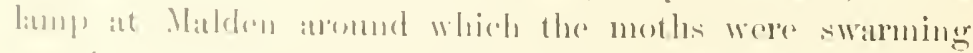

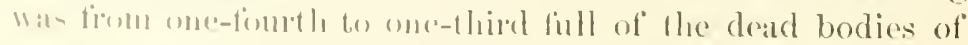
How menthe. Wishing to make a count of the number of menthe thus destroyed hy the lamp, Mr. Kirkland visited it at 5..30 the following moning : hat at that hour the sparrows wree atrely feeding on the moths in the lamp globe, and 
also carrying them to their young. July 16 other are lamps were examined at $4.30 \mathrm{~A} . \mathrm{M}$, , but even at that time the birds had anticipated the observer, and were carrying ofl the moths in large numbers. At 5.30 the sparrows had emptied the globe of moths, and also consumed the inseets on the ground underneath it. It was observed at 4.30 that there were sixteen male and two female moths on the lamp pole, but at 6 A.M. the birds had consumed all of them.

On the afternoon of July 16, at a time when the moths were still emerging, a drive through the worst-infested distriets showed only three brown-tail moths on lamp poles or tree trunks. There were plenty of the moths in sheltered places in the trees and under the leaves of rank herbage on the ground, but those in conspieuous positions had been destroyed.

Below in given a list of birds known to feed upon the brown-tail moth in any of its stages:-

Yellow-Jilled enckoo.
Black-billed 'nckoo.
Kingbird.
Blue jay.
Baltimore oriole.
Rose-breasted grosbeak.
Indigo bird.
Scarlet tanager.

Red-eyed vireo.

Yellow-throated vireo.

Black-and-white warbler.

Chestunt-sided warbler.

American redstart.

Chickarlee.

American robin.

English sparow.

\section{Fool) PlaNTs.}

That the farorite food of the brown-tail moth is the pear tree is very unfortunate, since there are fow places in the Enited States where pears are more sucensfully cultivated than in castern Massichusetts, - indeed the pear orehards of Revere and Arlington have a reputation not limited by State boundaries. Next to the prar the apple is preterred by the caterpillars, although they bred freely on stone fruits. and also on the chm, maple and serreal sperifes of oak. When the eaterpillan's swarm forth firom overeroweded aolonies, they seem to exereise but little scelection in the matter of food, but feed generally upon all deeiduous trees, on matny shrubs and even upon herbatre. A list of plants upon which the eaterpillars have been found feeding is given below :- 
Barberry, - Berberis mlgaris. basswod, - Tilia 1 meri-. relince.

European linden, - Tiliu Euiopuea.

Horse-chestuut, - E E s c ulus Hiprorcustronum.

Sugar maple, - Acer sacehurinnm.

White maple, - Acer dasycarpum.

Cut-leared maple, - Acer dasycarpull, var. Weirii.

Red maple, - Acer rulrum.

Box elker, - Negunder uceroicles.

Variegated box elder, - Neyund" acerviles, var. "uriegutu.

Stag-horn sumach, - Rlues typlinu.

Smooth sumach, - Rhus glubra.

Simoke tree. - Rhus Cotiulus.

Locust, - Robinia Psenducrriu.

lieach plum, - Prunus muritime.

Wild red cherry, - Prunus l'ennsylertuicu.

Chole-cherry, - Pinmus risginieru!.

d)amson plum, - Prunus domesticu.

Purple-leaverl plum, - Prmnus Pissureli.

Apricot, - Pinmess Limpniurte. Japanese plum, - Prunus .Juponice.

Meadowsweet, - Spirru sulirifolia.

Thimbleberry, - R" hus nceidentalis.
Dwarf wild rose, - Rosa lucirla.

Rose, - Rosa nitida.

Cholie-berry, - Pyrus arbutifolia.

Pyirus pimnatifida.

English hawthorn, - Cratregus Oxyacantha.

Paul's thorn, - Cratergus coccinea, var. Paulii.

Cockspur thorn, - Cratcegus Cirus-gulli.

Shad bush, - A melanchier Cunadensis.

Quince, - Cydomia vulyaris. Japan quince, - Cyclonia .Juponice.

Common red currant, - Ribes rubinm.

Black currant, - Ribes nigrum. Gooseberry, - Ribes !rossuleriu.

English gooseberry, - Ribes Ueu-crispue.

Witch hazel, - Ilumumelis Virginiune.

Flowering dogwood, - Cormus glorilla.

Cornus mus.

Arrow wood, - riburmum acerifolille.

Arrowwood, - Viburumm dentutum.

Black haw, - Viburnum prunifilium.

Hiegelia rosen.

Lister puniceus.

Sweet pepperbush, - Clethra uluifoliu.

White ash, - Fraxinus Americence.

Red ash,_- Fraxinus pubescens. 
Blue ash, - Fraviuns gumedrongulatu.

Black ash, - Frurimss sembucifoliu.

Common lilac, - Symingu melgaris.

Japanese lilac, - Syringu $J_{(1-}$ ponica.

Slippery elm, - Clmus fielvus.

White elm, - Ulmus Anericana.

Cork elm, - Ulmus racemosa.

English elm, - Ulmus cumpestris.

Seotch elm, - Ulmus montena.

Red mulberry, - Norus rubru.

Tartarian mulberry, - Morus: Turturica.

Syeamore, - Plutunns occidentalis.

Black birch, - Betulı lentu.

Yellow bireh, - Betulu lutere.

White bireh, - Betulu populifolia.

Paper birch, - Betulu prepyriferce.
Cut-leaved birch, - Betula alba, var. laciniutu.

Hop-hormheam, - Ostryu Viryinime.

White oak, - Qnerens allu.

Swamp white oak, - Qnercus bicoler.

Red oak, - Quercus rubra.

Scarlet oak, - Quercus roreinea.

Black oak, - Quercus coccinea, var. tinctoria.

Pin oak, - Quercus palustris.

Scrub oak, - Querens ilicifoliu.

Chestnut, - Custanea satilu, var. Americana.

Blue beech, - Cuppinus Carulimianu.

American beech, - Frengus firrugineu.

Purple beech, - Fu!nus s!yleaticu, var. purmene

Crack willow, - Sulix fragilis. White willow, - Salix allu.

Weeping willow, - Sulix Bab!ylomicu.

Heart-leaved willow, $-S u l i x$ corlutu.

\section{REMEDES.}

Wel, Instrulelion.

In the case of the brown-tail moth, action looking to the prevention of damage by the catcrpillars is of more importance than the applieation of renedies after the inserts have commenced feeding. W"ith this insect the tratitional "omner of prevention" is worth many "pounds of cure." For nearly six months, or, gener ully speaking. from the first of October to the first of April, these inseets are massed together within their silken winter webs. These webs, als already pointed out, are attached to the tipss of the twigs, are grayish-white in color, and easily seen when the foliage 
has fullen from the trees. In the ease of either fruit or shade trecs of ordinary size, nothing is eawier than to cut off and burn the wobs. The success of this operation was early discorered, and European treatises on the moth make particular mention of this method for conbating it. The wellknown European laws concerning the brown-tail moth lay particular stress upon this destruction of the winter webs; ant, in fiut, it is the essential feature of the fimous French law of "erhenilluye."

For the work of wob destruction there will be recuired ladder's of suitable length, stout clothing, and some form of pruning shen's attached to a long handle, the so-called "Water"s prunce" being the one generally used. It has been found that this work (an be done nore rapidly and theroughly by two men, one on the ground to discover and point out the webs, the other cutting them ofl while in the tree. All webs remored in this nanner should be earefully grathered in bages or baskets, and destroyed by fire. A careful scries of experiments made at the insectary of the gypsynoth rommittee in the winter of $1897-98$ showed that, if these webs are left upon the sround, the vitality of the inserets is not destroyed by the artion of the elements, and that a considerable perecutage of them will emorge unhatrmed the following spring. In this experiment, ats conducted by Mrr. Kirkland, a number of brown-tail moth webs were spreat upon the ground in a single layer in the fall, and covered with a piece of course poultry netting: thus the wets were axposed throughout the winter to rain, snow, frecring and thawing. The following spring, as soon as the

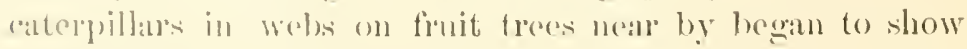
signc of arotivity, the webs were taken from the ground

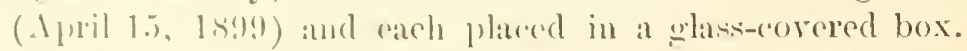
The larve commeneed to anerere soon after the webs were

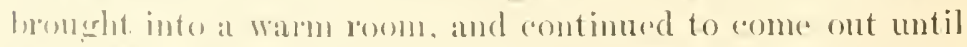
April 22. April sti, as no more larvie came from the webs, they were destroyed. In all, 19 wobs yielded larvas, while

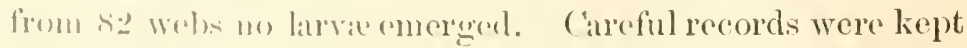

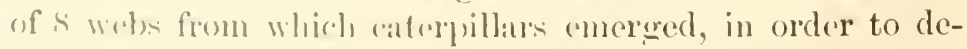
termine the number of larvae coming from anch web. The result-are tabulated below:- 
Plate 1:.

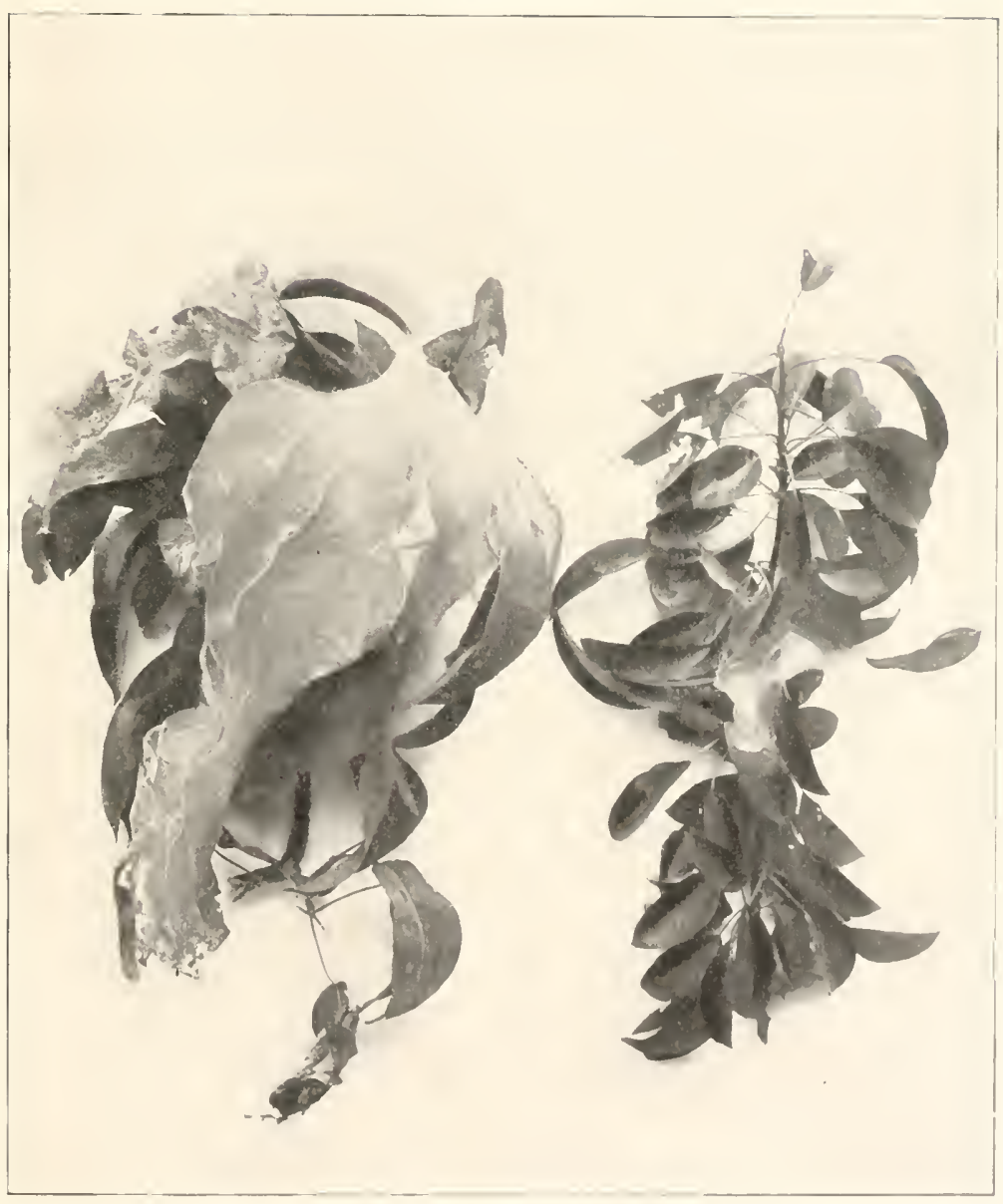

Fall web worm and brown-tail moth contrasted. On left, loose open web of web worm; on right, compact web of brown-tall moth. l'hoto, Matden, Mass., Aug. 9, 1s!!?. 



\begin{tabular}{|c|c|c|c|c|c|c|c|c|c|c|c|c|c|}
\hline & & & & & 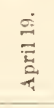 & $\begin{array}{l}\stackrel{\Delta}{:} \\
\vec{E} \\
\vec{E}\end{array}$ & 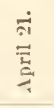 & $\begin{array}{l}\text { 宫 } \\
\bar{\Xi} \\
\stackrel{\bar{\Xi}}{-}\end{array}$ & 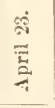 & 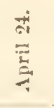 & 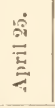 & 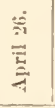 & $\frac{\frac{\infty}{5}}{\frac{5}{5}}$ \\
\hline No. 1, . & . & & & . & 16 & 3 & 7 & 4 & - & - & - & - & 30 \\
\hline No. 2, . & . & . & . & . & 2 & 6 & :3 & 13 & - & 1 & - & - & 25 \\
\hline No. 3, . & . & . & . & . & - & - & 17 & 70 & - & 10 & 1 & - & 98 \\
\hline No. 4 , . & . & . & . & . & - & - & 10) & 11 & - & 12 & - & - & 33 \\
\hline No. 5, . & . & . & - & . & - & - & 2 & - & - & - & - & - & 2 \\
\hline No. 6, . & . & - & $\cdot$ & . & - & - & 16 & - & - & - & - & - & 16 \\
\hline No. 7, . & . & - & & . & - & - & - & 2 & - & - & - & - & 2 \\
\hline No. \&, . & • & . & & . & - & - & - & 5 & - & - & - & - & $\delta$ \\
\hline Total, & & . & & . & - & - & - & - & - & - & - & - & 211 \\
\hline
\end{tabular}

This gives us an average of $26 . .3$ larve per web emerering unhamed; the arerage normal web eontains about 290 larvie.

It is preferable, where circumstinees permit, to burn the webs in a furnace or stove, thus insuring their complete destruction. Where the webs are burned in a bonfire in the field, it often occurs that a part become eovered with ashes and are not consumed. In a case noticed by one of the writers, some years ano, a number of webs that hat been partly seorehed in a boufire were still found to contain living insects. Silk is an excellent non-conductor of heat, as well as of cold; and in this casc, while the webs proterted the caterpillars from the rigors of winter, they also preserved a part of them unharmed from the artion of fire.

\section{s'praying.}

There will always be calses where the work of web destruction has been neglected, from one cause or another, too often from the indolence of the property owner. When the caterpillars emere in the spring and commence feeding on the young buds and leaves, the best remedy is to spray the tree promptly and thoroughly with arsenate of lead, using 3 or 4 pounds to 50 gallons of water. The insecticide 
should be thoroughly applied to the leaves, particularly in the part of the tree where the insects are feeding. In cases where trees cleared of the aterpillar webs stand near infested trees, they may also be preserved from damage by the migrating eaterpillars by a thorough spraying, as above indicated. Where arsenate of lead camnot be obtained, Paris green may be used, at the rate of 1 pound to 1.50 gallons of water, keeping the mixture well agitated while spraying. In the case of shade trees, this spraying should he done as soon as the foliage develops; and the same rule holds good with fruit trees, where the insects are abundant. If the trees are not hadly infested, however, it is often desirable to wait until after the blossoms have fallen before spraying, thus securing a double benctit by destroying the caterpillars of the hrown-tail moth, and also preventing damage to the fruit by the codling moth.

Where neither the wob destruction nor early spraying has been practised, it often oceurs that the caterpillars, nearly full grown, are found devastating the foliagre of the neglected trees. Where the insects are nearly mature, spraying with arsenical poisons does not always grive satisfactory lesults, for the reason that a great many of the insects disturbed by the spraying will pupate without feeding longer. In such cases it is more sat isficetory to prepare a quantity of strong kerosene emulsion, then jar the eaterpillars from the frees by beating the latter with poles. The insects filling to the ground should be thoroughly drenched with the kerosene emulsion, applied rither with a sprayer or frem a wateringretot. Trees freed from the caterpillars in this way, and also nom-infested trees standing near those on which the caterpillars are foeding, may bre easily preserved from damage by banding them with some sticky material, smb at the German ratpenleim, or its American substitute, bodlime, ore eren with tar or printer's ink. These materials. properly applind, form a sticky band over which the inseets camnet pass. 


\section{Bunding.}

In using tar or printer's ink, it is best to first apply a small band of cotton waste or wool, then tack orer it a band of tarred paper, to which the ink or tar is applied directly. These bands should be repainted at intervals of a few days, until the caterpillar season has passed. The bands of lime (either raupenleim or bodlime) are applied directly upon the bark. The bands should be from two to three inches wide, one-half inch thick at the bottom, tapering upward to the bark, in order to shed rain. The bottom of the band should be shaped to form a sharp shoulder. It is the tendeney of inseet lime to yield up a small quantity of oil under the influence of the sun, thus keeping the lower edge of the band always moist and sticky, and presenting an insurmountable barrier to the insect.

When the insects have pupated, the coeoons nay be gathered and destroyed, although this work is usually attended with a severe nettling of the skin, described in another place. Cocoons and pupe thus gathered should be placed in a barrel covered with mosquito bar, so that the parasites contained in them may escape, while the moths will be mable to pass through the netting. In the ase of the brown-tail moth this precaution is an exeellent one, as this insect is extensively parasitized in the pupal stage.

\section{Serond Broorl.}

It often oceurs in badly infested localities that the small caterpillars hatching from the eggs oecrir in suflicient numbers to partially or entirely defoliate the infested trees. This damage does not occur on trees which late becn thoroughly sprayed with arsenate of lead the precoding summer. Where the insects are numerous, a fill spraying with arsenate of lead is recommended, exeept in the case? of trees in fruit, sines, where the fruit is within a fow weeks of ripening, it is not alvisable to use the very adhesive as well as very poisonous spray. (Plate 11.) 


\section{IXNLCTIIIHS.}

For the work of spraying the foliage, no poison is more eflection than the arsonate of lead. This material is of light sperific mavity, hene remains well suspended in the spraying solution, and insures an even distribution on the foliage. It does not kill puite as atuickly as Paris green, but is very eflective against the insects when used in the proportions directed. It hats two special advantages, in that it sticks to the foliage tenaciously throughout the season, and will not seorch or injure the most delicate leaves. It is slightly nore expensive than Paris green or London purple, if the first cost of the material only is considered. On the other land, as one spraying is often sufficient to preserve a tree unlarmed from lat-eating insects for an entire season, while repuated spraying of Paris green are necessury, the arwenate of lead often proves the eheaper insecticide.

\section{$1 / 0 n$ mede.}

Arsenate of load may be prepaned by dissolving separately 3 pants commeredial nitrate of lead and 1 part commer(ial arsenate of soda and pouring the two solutions together, when the arsenate of lead is flung down as a dense white precipitate. This formula is based mpon the arerage grade of nitrate of kead containing 66.5 per cont. lead oxide, and al'senate of soda containing 59.s pere cent. arsenic oxide. ()wing to the difleulty in obtaining these chemieals in small quatitices at a fitir price, and the uncertainty as to their purity, the suall usere will do well to purehase some one of the prepared forms of arsenate of lad now oflered in the mallewt, instead of attempting to mamufacture the insecticide. ()wing to the increasing use of arsenate of lead for spraying purpesese several reliable manufacturers have put it upon the marken in the form of a paste, which is ready for use as sucul at water is adderl, thus being at onee convenient and inexpensive.

If laris enceen is used, a strength of 1 pound to 150 galllons of witere will give groed results, and the proportion of poison should not be greater than 1 promed to 100 gallons, 
Plate 1:3.

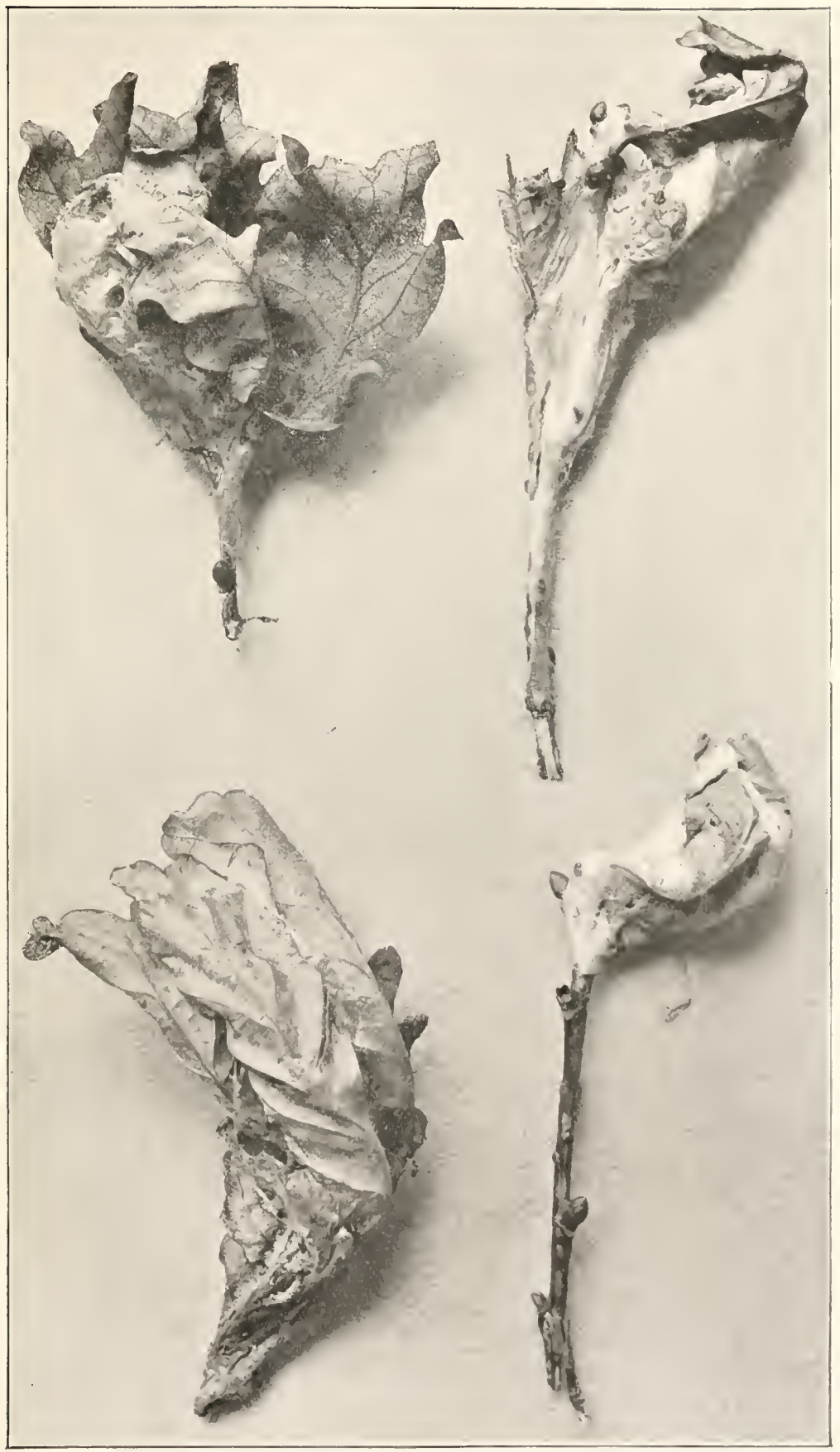

Winter webs of brown-tall moth on English oak.

rhoto loaned by Chas. Iradley, supt. Farm school, Thompson's stand. 

otherwise burning of the foliage will oceur. In using Paris green, it should be borne in mind that this insecticicle has a high specifie gravity and settles rapidly in the spraying tank, hence it should be stirred continually while being applied.

Kícrosene emulsion, useful in destroying caterpillars jarred from trees, and on fences, walks, ete., is made by dissolving $1 / 4$ pound hard soap in 2 quarts of water, and adding to the solution, while hot, 1 gallon of kerosene oil, stirring the whole, or pouring it rapidly from one pail to another until a stable white emulsion is formed. This emulsion for use on the caterpillar's should then be diluted at the rate of 1 part emulsion to 5 of water. At this strength there will be some injury from the kerosene to grass and other foliage, but the effect on caterpillars will be more satisfactory than where the normal dilution of 1 part to 9 of water is used.

\section{Apparatus.}

The damage by the brown-tail moth is as sererely felt in proportion to the value of the erop in the kitehen garden as on the farm. In fact, owing to the scarcity of native insect-cating birds in our cities, injury by caterpillars of this class is sometimes more severe in cities than in the open comntry. While the eity owner requires the same spraying matcrials as are used on the farm, his needs in the line of apparatus are much less.

For use in a kitchen garden or on a small estate, exeellent results in spraying can be obtained from a brass syringe, such as is commonly used in greenhouses for showering plants. I suitable syringe can be bought for about $\$ 4$, and by its use regetables and fruit trees of good size may be sprayed satisfictorily.

On larger estates, and particularly where shrubbery hats a prominent place, no outfit is more comrenient and germerally useful than a copper knapsack spray pump. Wr might add that nothing is more wearisone to the flesh than to carry one of these outfits on at hot diay, but suche labor often pays big dividends. The writers would advise anainst the purchase of galvanized-iron knaljarckis: these soon lust out, 
two years being about the limit of their nefulness. On the other hand, a colper linapsack pump, costing at the start ahout $\$ 1 \%$, if properly cared for will last ten or fifteen yeitl'. It is important that it be thoroughly washed with clean water after using.

In orchards and for general work against the brown-tail moth and other insects, a substantial spray pump, mounted on a 50-gallon cask, is a necessity. Such a pump should lave brass working parts, an eflective agitator, and an air chamber of ample capacity to equalize the flow of the spray. The price of pump and cask ought not to exceed $\$ 12$ or $\$ 15$. In addition will be needed 50 to 100 feet white cotton hose, costing about 10 eents per foot; an 8 or 10 foot spray pole extension, $\$ 1$; and a Vermorel nozzle, 60 cents, - these fignres being approximately correct for present market conditions. It' desired, the spray pole can be made by any plumber from a piece of one-fourth-inch gas pipe. At the lower end a hose nip (reducer) shonld be inserted to receive the end of the hose; the other end shonld be threaded to serew dircetly into the nozzle.

For extensive spraying operations, such as are necessary in larese orehards, parks, and reperially where tall shade trees are to be sprayed, larger and stronger pumps will be required. In these operations it is often desirable to use two or more lines of hose, often against a head of serentyfive to 100 feet. I jump suited for this work must have "ylinders of anule capacity, a large alr chamber and a rigid frame and base. From s.5 to $\$ 30$ will cover the cost of surh a pump. Other details will be about as follows: suction hose, fittings, strainere, cte., $\$ 5: 200$ fect hose, $\$ 20:$ two spray poles, sz: two nozkles, $\$ 1.20 ; 150$-gallon hogshead, \$1.i(1. In outfit of this class is suited for the largent smatying operentions, such as park or eity work, as well as for "xtensive orehard sprayings. At Dedham, Jpswich, Priderewater, Iawrence and wewhere street elms have been - prayed with outfits of this deseription, with highly satisfatefory results. 

Plate 14.

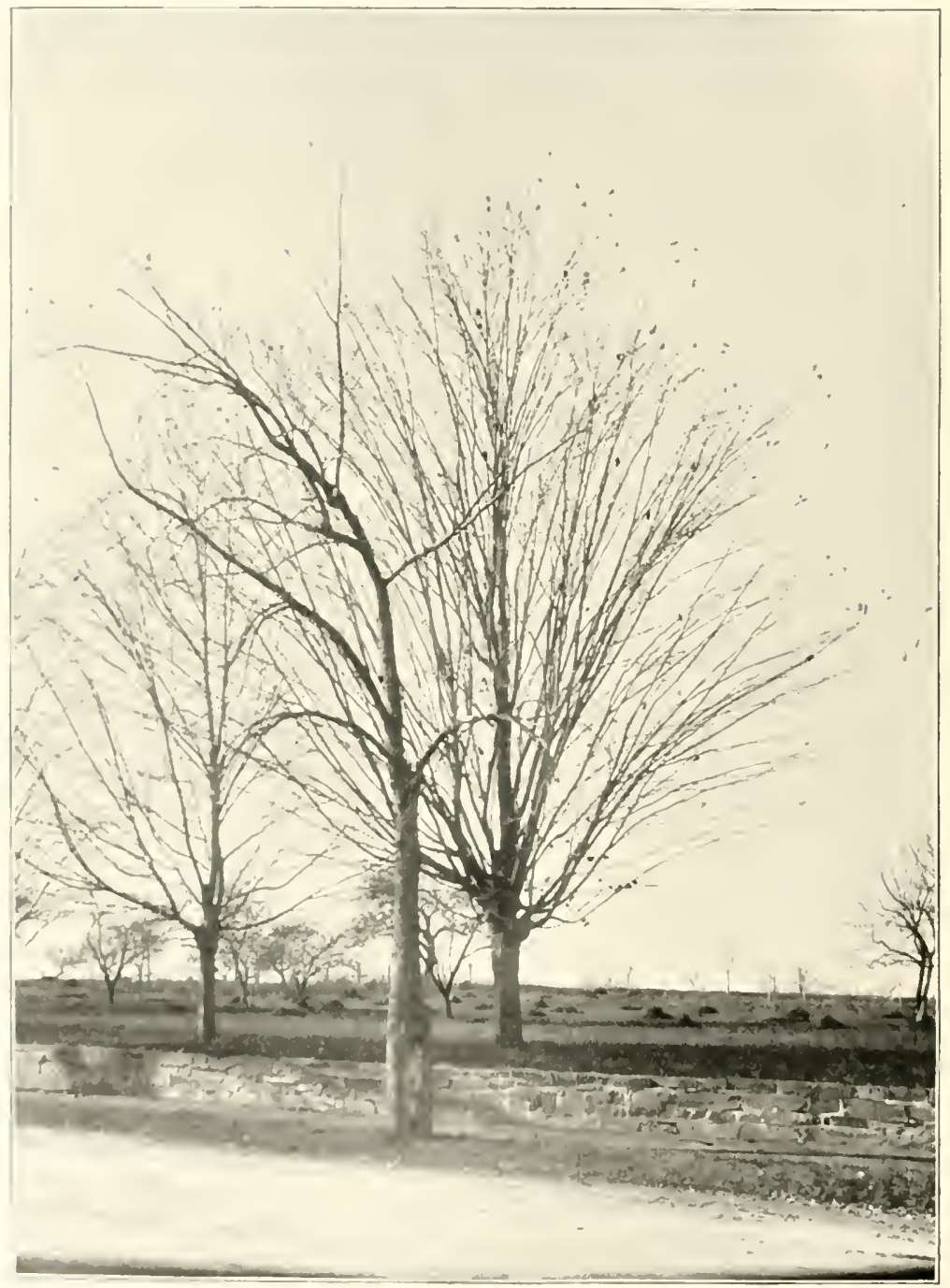

If netr webs w brown-tall moth on American elm and rock maple, Modford, Mass., Nov. 20. 1899. 


\section{How to sprely.}

One might suppose that the spraying of a tree or a plant was a simple operation, requiring but a modicum of skill and intelligence. This view doubtless is responsible for a large part of the failures in spraying, for particular eare and attention must be given both to the mixing and the application of the insecticide materials, in order to obtain satisfactory results.

Assuming that the proper materials in proper quantities have been obtained and mixed according to directions, a suitable outfit provided, and the water used carefully strained, the work of spraying may be commenced.

Where trees are treated, spraying should commenee at the top. If the wind is blowing, the work should be carried on from the windward side. Often in a breeze of low velocity large trees can be thoroughly sprayed from the windward side alone, the mist being drifted on the air.

The spray should be applied as a fine mist, never in a stream. The dew remains on the leaves; the rain runs off. The same is true of spraying; a mist adheres, but drops run off. The nozzle should have a very small aperture, and, if baeked by a pump of adequate power, the spray will burst forth as a fine mist, which should be allowed to diffuse in the air before striking the foliage. Hence it is desirable to hold the nozzle a few feet from the leaves to be treated. In all cases spraying should cease as soon as the foliage begins to drip.

\section{SPRATING ENPERHENTs.}

Numerous experiments with insecticides on brown-tail moth lanve were earried on at the insectary of the erysy moth committee. So thoroughly, however, had this field of experimentation been covered in the case of the eypey moth, that few alditional facts of value were discovered. Certain field experiments unon the brown-tail moth aterpilkars are of particular value, however, as showing results obtained under the atetual conditions which confront the property owner having infested trees.

In May, 1898, there were secured for experimental pur- 
pons a large number of pear trees, from ten to fifteen feet high, standing on an estate in the southern pant of Malden. 'There trees were thoroughly and puite uniformly infested with the hrow-talil moth, and the caterpillars hat emerged and commenced feoding, being at the time of the experinonts in the second and thind molts. In ach case these treses we sprayed with variodis insecticides, as given below. In the case of alsenate of lead, the quantitic's mentioned represent the actual dry arsenate of lead contained in the ingredients used.

\section{Field Experiments.*}

1. Arsenate of lend, 1 pound to 100 irallons of water:-

\begin{tabular}{|c|c|c|c|c|}
\hline Muy 19. . & sprayeal. & May $2 \bar{\pi},$. & 90 per cet & t. dend \\
\hline May 20, . & no results. & May 2x, . & - & - \\
\hline Many 21.. & no results. & May 2!, . & - & - \\
\hline Mụ 22, . & reatsed frecling. & Maỹ 30, . & - & - \\
\hline Muy 2:3, . & 50) per cent. dead. & May 31, . & - & - \\
\hline May 24,. & - & June 1 . & - & - \\
\hline Muy 25. & - & Jume 2, . & all rlead. & \\
\hline May $24,$. & - & & & \\
\hline
\end{tabular}

2. Arsemate of lead, 2 pounds to 150 gallons of water :-

\begin{tabular}{|c|c|c|c|c|}
\hline Muy 19, & . spriagert. & May $27,$. & . (!) per cee & 1. dend \\
\hline$M: a y=11,$. & no results. & May zx, & - & - \\
\hline Mity 21,. & no resilts. & May 29, . & - & - \\
\hline Mry 2.2. & rensed lieredingr. & May $30,$. & - & - \\
\hline M:1y z:i, . & 5() per cent. deacl. & May 31, . & - & - \\
\hline Muy $\geq 1$. & $-\quad-$ & Jume 1 ,. & - & - \\
\hline M:1y 2:4, . & - & Jume 2,. & - ull ılead. & \\
\hline Maty $24 ; 0$. & - & & & \\
\hline
\end{tabular}

3. Arecuatu of legrl, 5 poumds (1) 150 grallous of water:-

\begin{tabular}{|c|c|c|c|}
\hline M:1y $1 ! 1,$. & spruyed. & May 25, . & - \\
\hline May :11, . & uo rioults. & May 26. & - \\
\hline Xuy 21 , & m results & Miy $2 \bar{t}$. & - \\
\hline$M_{n y} \geq 2$. & ("rinsinl feredingr. & May 2র. & - \\
\hline V:iy : 2:i, . & sll per corth. dersel. & May 29, & all deat. \\
\hline Muy 21, . & $-\quad \quad-$ & & \\
\hline
\end{tabular}

1. Ar-11:tle of leitl, 11) poumds to 150 gallons of water:-

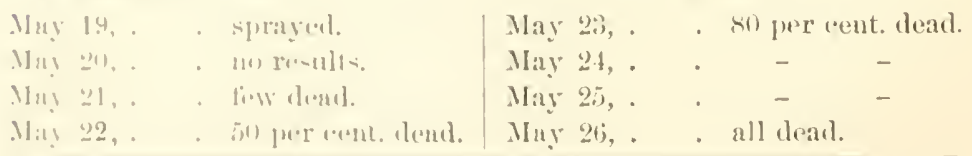

- Hon pumbl irsthate of leath as used in these experiments is equal to about

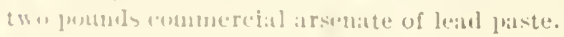


5. Paris green, I pound to 150 gallons of water :-

\begin{tabular}{|c|c|c|c|c|c|}
\hline \multirow{3}{*}{$\begin{array}{l}\text { May } 19 \text {, . } \\
\text { May } 20 \text {, . } \\
\text { May } 21 \text {. }\end{array}$} & . sprayen. & May 26, . & & \multicolumn{2}{|c|}{70 per cent. dead. } \\
\hline & . no results. & May 27, . & & - & - \\
\hline & . no results. & May 28, . & - & - & - \\
\hline May 22 , . & 10 per cent. dead. & May 29 , . & & 90 pe & nt. clead. \\
\hline May 23 , . & 50 per cent. dead. & May 30, . & $\theta^{\circ}$ & - & - \\
\hline Maş 24 , . & $-\quad-$ & May 31 , & • & - & - \\
\hline May 25,. & - & June 1, • & $\bullet^{\bullet}$ & all de & \\
\hline
\end{tabular}

6. Scheeles green, 1 pound to 150 gallons of water: -

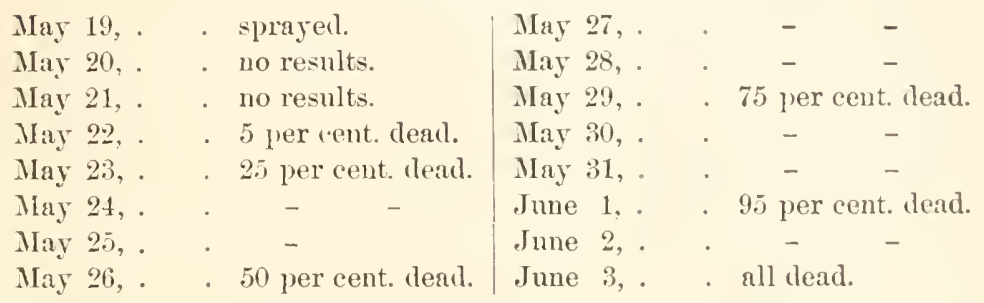

In the fall of 1898 , while the newly hatehed caterpillars were still feeding, a number of trees at Malden were sprayed with arsenate of lead at the rate of 12 pounds to 150 gallons of water. As the webs were nearly formed at this time, it seemed desirable to keep a certinin nmmber of them, to determine whether the poison had killed all of the (aterpillars. Later, in April, 1899, the webs were placed in a warm room and isolated, with the following results:-

24:3 webs on pear : -

April 26, April 27 , April 2s, April 29, April 30,
4 webs rielded larve.

25 webs yielded larvie.

5 wehs yielded larvix.

- webs yielded larva.

- webs vielded larra.

34 , or $1+t$ per cent.

A number of webs had also been gathered under exactly identical conditions from entain large chn trees that lat been sprayed as thoroughly as posible at the same time and with the same strength of poison. These webs'yelded many more larve as will be seen by the table below :- 
237 webs on elm :-

April 26.

April 27 .

April 28,

April 29

April :30,
. 101 webs yielded larræ.

10 webs yielded larra.

12 webs yielded larva.

- webs yieliled larre.

3 webs yielded larrie.

126 , or 53 per cent.

These figures show clearly that fill spraying is not an exterminative method, probably for the reason that some of the insects enter the webs early to hibernate. It is also rery interesting to notice the diflerence in the eflectiveness in the spraying of laree and small trees. The pear trees were easily reached by ladder's, and thoroughly sprayed. (1) the laree ohus thorough work was also attempted and much time and labor spent in spraying them, but the results were only onc-fourth as satisfivetory. These figures also have a wider significance, in showing us how difficult it is to get entirely satisfactory results in spraying large trees.

\section{MiNicimal Work.}

The adrent of the brown-tail moth in Massachusetts and it- eradual distribution in thickly settled districts gives another exvellent illustration of the interdependence of all ritimans in a community where matter's of public good are at stake. Where the moth oceurs but scatteringly, its ratages are slight and the pest is easily controlled. The "as is far ditlerent, lowerer, when the insect is numerous;

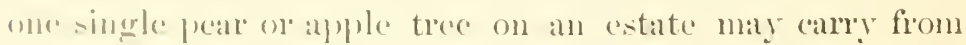
one to two humcherd webs, ache web containing, on the averatere, two hunded and fifty aterpillars. The insect

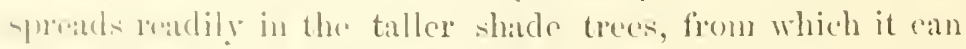
ouly le alcared at a great expense. Even if the property owner sueereds, at the outlay of much time and money, in findue lise place from these inseets, his labors are matailing- hould his meighbor, through ignorance ol carelessness, allow the treeses on his estate to remain badly infested.

$1 V^{\prime}$ have sem repeaterly in the metropolitan district mumene illu-trations of the annoyane and damage thus

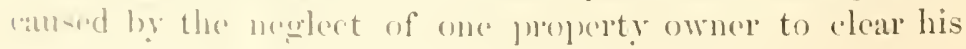


trees from the insects after his neighbors had lestroyed the webs on their own trees. This matter of web destruction is often an expensive undertaking. Many property owners can ill afford it; certainly tenants cannot, as a rule; while the non-resident owner is very apt to neglect this work. Clearly, then, this is a case where co-operation is a necessity, if the moth is to be held in eheck : and, lacking state supervision of the work, munieipal enterprise oflers the most promising means of relicf.

Under our present laws, municipal officers have the power to enter on private cstates for the purpose of suppressing dangerously injurious insects: and it is the opinion of the writers that the control of the brown-tail moth clearly falls within the field of legitimate municipal enterprises.

This pest is certainly a menace to the property and wealth of eitizens, while by its attacks on strect trees it directly destroys the property of the eity or town where it occurs. The good of the community demands that the brown-tail moth should be suppressed, and in no way can this be done more economically than through the direct and systematic work of some municipal department, preferably the one having in charge the parks or streets. In this way all tax payers in a community, sharing, as they do, in immunity from damage by the moth, also share in the cost of its suppression.

A campaign against the brown-tail moth is best begun in the fall or early winter, preferably in lecember, after the leaves have fallen from the trees. A preliminary seouting or examination of the territory is always of advantage. as showing where the moth is thickest, and the amount of work necessary for its suppression. If the municipal appropriation is of adequate amount, the whole regrion should bo earefully worked over, and all wobs destroyed, in ordar lo prevent the local increase of the moth and its further spreal the following summer. Where, as is too often the ease, the aplropriation is a linited one, the worst infestations shomld be attended to in a thorough nimmer. It is but folly to spend money elearing tall street trees from the webs of the 
caterpillar while in adjacent yards there stand pear trees bearing hundreds of webs within easy reach. Dense infestations should be stamped out first of all, to prevent a serions caterpillar outbreak the following year, with its ("onserpent damage to property and persons. Later on, the more thinly infested districts should be worked over so far as funds permit.

From three to ten men can be profitably employed in a gang, while several gangs may be placed under one foreman or inspector. Maps showing aecurately the location of the primipal infestations, together with the streets included therein, should be in the hands of the foreman, in order that al proper record of each day's work may be made, and thus preserved for future reference.

The importance of destroying the moth on private estates as well ats on street trees has already been pointed out. ["sually where this has been attempted by municipal authoritir- it has met with the approval if not co-operation of prop"rty own's. Since, however, previous to 1902 there was no law anthorizing municipal authorities to enter mivate grounds for this purpose, a special act eonferring the desired anthority" upon them seened desirable. The following law Wils (matcted F(b). 5), 1!102:-

[CHAPTER 57, ACTS OF 1902.]

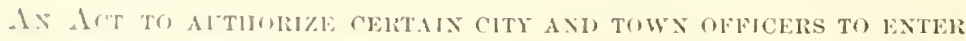

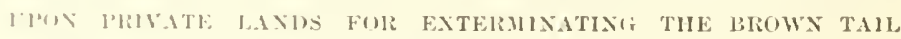
YOTI AXW OTHER SMHLAR PLSTS.

Be il inecled, t tce, as follows:

Shotox 1. Whenever the hrown tail moth, the elm-leaf beetle, ar :my cther tree or shoub destroying pest shall bo discovered in aty aity or town of the ('ommonwalth, such eity or town, by the municipal oflicar of ollicers to whom the are of the shatde trees

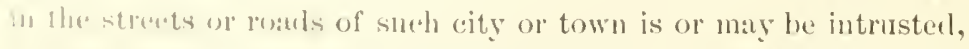

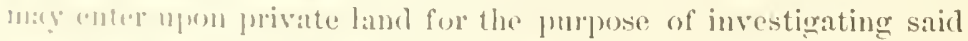
frel, and maty adopt reationable measmes to prevent its spread and th - mone its externination.

Sirture. 'The owner of any land so entered upon, who shall -uffel daruage ly such entry and acts done thereon nnder the anthority harin given, mas reesere the same of the city or town in which the lands so asserted to have been damaged are situated, 
by action of contract; but any benefits received by such entry and the acts done on such lands in the execution of the purposes of this act shall be determined by the conrt or jury before whom such action is heard, and the amount thereof shall be applied in reduction of said damages.

Section 3. Whoever shall oppose the entry aforesaid, or obstruct the performance by the sairl local anthorities of said work. shall be punished by a fine not exceeding twenty dollars for each offence. 





है 
